\title{
The Bohemian Royal Towns (Pilsen, České Budějovice, Cheb) under the Power of Matthias Corvinus"
}

\author{
Martin Šandera
}

vol. 9, 2020, 1, pp. 6-44

DOI: https://doi.org/10.33542/CAH2020-1-01

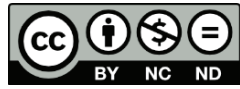

This study deals with the fate of the only three Czech royal towns, which during the protracted conflict over the Czech throne (1468-1479) declared themselves under the auspices of the Hungarian ruler Mathias Corvinus (České Budějovice, Pilsen), or had his authority under the title of King of Bohemia (from May 1469) successfully applied over them (Cheb). It reveals the motives for their leaning to the side of Mattias Corvinus and analyses their positions as military powers and, to a lesser extent, intelligence centres, deals with the changes in the holdings of real estate property in the towns in the course of Corvinus's reign, and shows the compositions of the town councils, their efforts to maintain independent political approaches (especially in the case of Cheb) and the development of their relations with the military command of the city. Attention is also paid to the ecclesiastical administration and cultural level of these municipalities during Matthias's reign.

Keywords: Late Middle Ages. Kingdom of Bohemia. Royal towns. Mathias Corvinus.

In April 1468, Mathias Corvinus declared himself the protector of all Catholics and on 3 May 1469 was elected King of Bohemia in Olomouc's Cathedral of St Wenceslas by parts of the Bohemian, Moravian and Silesian estates, although the existing Bohemian sovereign, accursed and deposed by Pope George of Poděbrady, did not intend to vacate the position. ${ }^{1}$ In Moravia, Silesia and Lusatia, Corvinus's position was strong; he controlled the vast majority of towns and only Uherské Hradiště and Uničov resisted him. In the territory of the Bohemian Kingdom itself, the situation was reversed, his real influence here being based on the private property of the aristocratic opposition to King George of Poděbrady, which in November 1465 joined in the so-called League of Zelena Hora. At the time of its greatest strength, this association had 62 castles and around 10 feudal walled towns. However, of the 42 Bohemian royal towns, only three recognized King Matthias as their lord - Pilsen, České Budějovice and later, under the heavy pressure of the Roman Curia, Cheb also. These towns thus from a geographical perspective represented the westernmost outposts of Mathias's power for the entire time of his reign.

The appearance and state of the towns at the close of the Poderbrady era

What was the actual state and significance of these three towns, which were to come under Corvinus's power, in the second half of the 1460 s? Pilsen and České Budějovice represented the natural centres of two of the Czech regions - the West Bohemian and South Bohemian, while Cheb was then an imperial territory, which since 1322 had been a hereditary pledge of Czech kings. All three municipalities were important trading centres and had high-quality fortifications. In terms of population and real estate

\footnotetext{
This study is the publication output of the specific research project of the Philosophical Faculty of the University of Hradec Králové for the year 2019: Bohemian Royal Boroughs under the rule of Mattias Corvinus.

1 KALOUS, Matyáš Korvín.
} 
inside the walls, these cities belonged to the category of the ten largest in the Czech Kingdom, and only Prague and Kutná Hora outdid them significantly.

Table 1: Comparison of area, population, property and church conditions

\begin{tabular}{|c|c|c|c|}
\hline & Pilsen & České Budějovice 2 & Cheb \\
\hline Population & Over 4000 & 4350 & 7600 \\
\hline $\begin{array}{l}\text { Area of the town } \\
\text { inside the walls }\end{array}$ & 20 ha & 22 ha & 31 ha \\
\hline Number of houses & 290 & 373 & 442 \\
\hline $\begin{array}{c}\text { Number of houses in } \\
\text { the suburbs }\end{array}$ & 58 & 22 & Undocumented \\
\hline Subject villages & $\begin{array}{c}\text { Skvrňany, Božkov, } \\
\text { Koterov, Cernice, } \\
\text { Radobycice, Útušice, } \\
\text { Doudlevce and part of } \\
\text { Lobez. Křivice }\end{array}$ & $\begin{array}{l}\text { Mladé, Vráto, Pohůrka, } \\
\text { Suché Vrbné, Hlinsko, } \\
\text { Dubičné, Šindlovy } \\
\text { Dvory, Vesce, Haklovy } \\
\text { Dvory, České Vrbné } \\
\text { and Litvínovice }{ }^{4}\end{array}$ & $\begin{array}{l}126 \text { paying villages } \\
\text { and settlements }\end{array}$ \\
\hline $\begin{array}{c}\text { Number of privileges } \\
\text { from George }\end{array}$ & 9 & 6 & 5 \\
\hline Churches and chapels & 4 & 4 & 10 \\
\hline Cloisters & $\begin{array}{c}\text { Dominicans, Minorites } \\
\text { + suburban spittal } \\
\text { field }\end{array}$ & $\begin{array}{c}\text { Dominicans } \\
\text { Spittal field of } \\
\text { St Wenceslas } \\
\text { administered by the } \\
\text { Order of Cruisers with } \\
\text { a red star }\end{array}$ & $\begin{array}{l}\text { Franciscans, and Poor } \\
\text { Clares, commandery } \\
\text { of the Order of the } \\
\text { Teutonic Knights, } \\
\text { Order of Cruisers with } \\
\text { a red star }\end{array}$ \\
\hline
\end{tabular}

The national composition of the population deserves attention as well. In spite of the fact that the native Czech King George enjoyed it here, it was a dominantly German city. České Budějovice was a town with approximately the same number of Czech and German inhabitants, but it was in Poděbrady's time that the Czech element underwent an emancipation, the property of Czech burghers grew and, during the era of the burgomaster Ondrej Puklice, their real influence on the town's operation significantly strengthened. A coup d'état in the city and the inclination to Corvinus's side were also related to the efforts of some German burghers to stop the growth of the Czech element, although there were also significant other motives. ${ }^{5}$ The Czech

2 VAŘEKA - ROŽMBERSKÝ - HOLATA - SCHEJBALOVÁ. Vesnické zázemí, 289-318. On that, see also the chapter on the Economic region of New Pilsen in MALIVÁNKOVÁ-WASKOVÁ - DOUŠA. Dějiny města Plzně 1, 133-136.

3 The book also presents the royal interest from 1446-1482 (Kniha královského úroku, 1446-1482; ČECHURA, České Budějovice, 166; and ČECHURA, Nová interpretace, 1-12. The territorial extent of the town villages was "de iure" closed by their entry in the land tablets in 1498 confirming for the town the free holding of the villages, see: ČELAKOVSKÝ, Codex luris Municipalis III, 915-916, Nr. 538.

4 SOkA Cheb, fund Nr. 1, book Nr. 1086, on that, see: KUBŮ, Chebský městský stat, 43.

5 BUKOÑOVÁ, Vztah královské politiky Jiřiho z Poděbrad, 344-382, 366-367. On the overall approach of George of Poděbrady to the cities, see: RAK, Česká venkovská královská města, 5-51. For a comparison with the Moravian milieu, see: SULITKOVÁ - BOROVSKÝ, Moravská královská města, 41-55. VONDRÁČEK, Panovnická 
element already had a majority in Pilsen and, according to the names of those on the city council, Czechs prevailed.

Pilsen and České Budějovice controlled the nearest surrounding villages, for the management of these cities can be taken as representative of the broader municipal estate, but it is not yet possible to talk about a city dominion, such as with nearby Tábor, which had nearly 100 villages under its influence. However, the real strength of Cheb meant not merely the town and the group of borough villages in the surroundings as in the cases of Pilsen and especially České Budějovice; it was a large area which the town ruled, and by the end of the fourteenth century it had clearly won over the local nobility: it is correct to speak of a Cheb town state, controlling a territory of around $380 \mathrm{~km}^{2}$ containing 160 villages and settlements. ${ }^{6}$ The prosperity and development of the town was contributed to by trade ties with Nuremberg and Regensburg. Orientation towards the Bavarian and Franconian regions of the Empire can be found near Pilsen. On the other hand, traders from České Budějovice preferred to trade with Lower Austria, where they went to buy mainly wine and salt.

\section{What motives led these towns to fall away from George of Poděbrady and at least temporarily recognize as their lord and soon also as the Bohemian king Matthias Corvinus?}

King George of Poděbrady was aware that unlike the majority of Czech towns Pilsen, České Budějovice and Cheb had remained Catholic towns with significant German populations and that their loyalty would need to be ensured. He tried to do so in two ways - by granting economic privileges to municipalities (here he was even more generous than with Utraquist towns) and by supporting and enabling property profits for those appointed as royal magistrate or burgrave. ${ }^{7}$ It was precisely the removal of these persons in Pilsen and České Budějovice that preceded the abandonment by both towns of King George, and it was actually a necessary condition for them to recognize Mathias Corvinus as their master over time. In both cities, the opposition forcibly disposed of the main representative of the pro-Poděbrady party, seized his property and took away the power of the existing burghers and their associates. Corvinus was supposed to be the one to ensure these groups their positions and profits, while guaranteeing that they would not face retaliation for their actions. And in both cities, the opposition dared to strike only after being urged by papal bulls to fall away from the heretical king.

Let us first pay attention to Pilsen. At the head of the party that wanted to maintain loyalty to King George stood Ondrej Oremus, whom the king in 1462 granted a magistrate's post with a comprehensive set of economic benefits. ${ }^{8}$ After the creation

politika vůči městům, 161-165. The king's careful approach to the opposition Catholic cities is accurately demonstrated by: CZECHOWICZ, 0 miejsce w koronie, 55-61.

6 KUBŮ, Chebský městský stat, 48-49.

7 BURKOŇOVÁ, Vztah královské politiky Jiřiho z Poděbrad, 366-367.

8 STRNAD, Listár̆ a listinár II, 89, Nr. 101. The city of Pilsen acquired a magistrate's office already in 1433, but only for four years. At the time of the so-called Post-Lipany Interregnum, courts were held in burgher houses (on "neutral ground"), not at the magistrate's office or the city hall. The return of the magistrate's office to the hands of a royal official was thus perceived by the city as a tangible intervention and the resentment mainly turned against Oremus, who was a Prague burgher by origin. The attempt to purchase the magistrate's office from the hands of the sovereign was characteristic of the absolute majority of Bohemian royal towns in the Late Middle Ages and represented an important step in the process of their emancipation from sovereign power. 
of the commemorative aristocratic opposition association of the so-called Zelená Hora League, Pilsen was contacted not only by its leaders but, on 29 December 1465, also by the papal legate Rudolf of Rüdesheim, who sent the city council a copy of the bull of Pope Paul II in which he relieves the Catholic population of their oath of loyalty to King George, and in the attached letter he says that the city does not have to respect the existing royal magistrate and can freely choose its own. ${ }^{9}$ Frightened, Oremus went to Prague for help and in his absence a bloodless coup took place in the city. The people of Pilsen elected new magistrates and quickly hired a mercenary troop to prevent the forces loyal to the king from regaining control of the city. Nevertheless, the conspirators were still so afraid of retaliation that they soon sent a letter of apology to King George, arguing that they could not resist the Holy Father, and even sent messengers to Cheb and Wroclaw for help against the royal troops. ${ }^{10}$ Nevertheless, Cheb remained loyal to the king, and not even Wroctaw provided financial or military assistance. However, thanks to the activities of the legate Rudolf of Rüdesheim, this largest Silesian city quickly took on the role of the main centre of the anti-Poděbrady resistance within the entire Bohemian crown and closely observed the behaviour of both Pilsen and later České Budějovice. ${ }^{11}$

Oremus returned to Pilsen accompanied by hundreds of royal riders, but the city refused to open the gates and Poděbrady's army decided against a direct strike in fear of great loss of life, did not resist and retreated to the people of Rokycany. Oremus was not admitted to the city even as a negotiator and his property was confiscated by the new rulers of the town. ${ }^{12}$

Pope Paul II appreciated the position of Pilsen and openly took the town under his protection, and he improved the city coat of arms, where in addition to a knight symbolizing the fight for the protection of faith St Peter's keys also appeared. ${ }^{13}$

9 Text of the legate's bull from 29 December 1465, STRNAD, Listár a listinár II, 113-115, Nr. 127.

10 The Letter of the People of Pilsen and the copy of the legates' letter have been preserved in the collection Cancellaria Regis Georgii, National Library of the Czech Republic, Collection of Manuscripts and Rare Printed Books, sign. XXIII.D.172, rukopis A, pp. 625-628; STRNAD drew from these for his Listár̆ a listinár II, 120-121, Nr. 132.

11 Thanks to the chronicle of the municipal scribe Peter Eschenloer in ROTH, Magister Petr Eschenloer. Geschichte der Stad Breslau 1, 2 and the excellently edited correspondence from the times of Poděbrady and Matthias in: MARKGRAF, Scriptores rerum silesiacarum; and KRONTHAL - WENDT, Scriptores rerum silesiacarum, Wroclaw is one of the crucial information sources also for the Bohemian Catholic cities of this period.

12 BĚLOHLÁVEK, Dějiny Plzně, 102-103.

13 Archiv města Plzně [Archive of the City of Pilsen] (hereinafter AM Plzně), Archiv města Plzeň (hereinafter AMP), Listiny, sign. I 182. Pilsen even received financial support from the papal treasury - STRNAD, Listár a listinár II, 151. On that, see also: ROTH, Magister Petr Eschenloer. Geschichte der Stad Breslau I, 518. The pope improves Pilsen's coat of arms by two new fields - Archiv města Plzně, sign. I 182, for the edition of the deed, see: STRNAD, Listár a listinár II, 138, Nr. 153. 


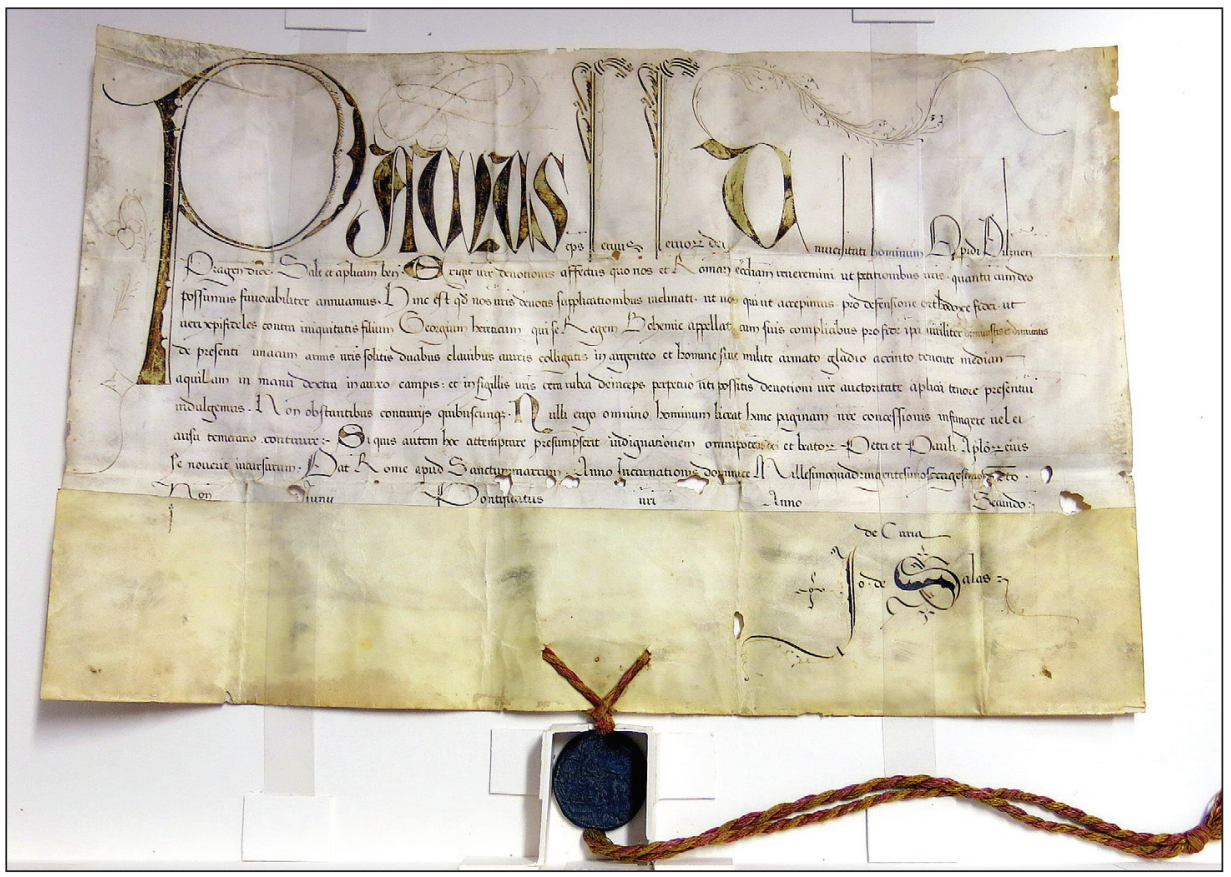

Figure 1: The bull issued by Pope Paul II to Pilsen, dated 5 June 1466. AM Plzeň, AMP, Listiny, sign. I 182.

The Prague metropolitan chapter and one of the main ideologues of the domestic resistance against King George - Master Hilarius Litoměřický - moved to the city. ${ }^{14}$ The city council came to be swayed by the agile clergy, which, however, did not purposefully subject the councillors to heightened verbal pressure and rather tactically projected the idea that maintaining order in the city could be guaranteed with certainty through fidelity to curial policy towards the Bohemian heresy. ${ }^{15}$

The main partner sought by the city for resistance to Poděbrady was the Zelená Hora League and it very much welcomed this position. In February 1467, Emperor Frederick III of Habsburg even granted the Zelená Hora League the right to mint their own coins in Pilsen. ${ }^{16}$ In March of the following year, the leader of the League, Zdeněk of Šternberk, met with Matthias Corvinus in Trnava, in April Matthias was declared the defender of all Catholics in the Crown of Bohemia and on 22 August 1468 in Olomouc

14 On Hilarius and his activity in Pilsen, see: FIALOVÁ, Z korespondence Hilaria Litoměřického, 68-89; HEJNIC, Hilaria Litoměřického, 240-245. KADLEC, Hilarius Litoměřický, 187-196. On his view of the city as the selected community in Bohemia for the battle with heresy, see: HEJNIC - POLÍVKA, Plzeň v husitské revoluci.

15 Unlike Wroclaw in Silesia, which was otherwise a model for Pilsen in some respects and with which it maintained written contact, it is not possible to speak of a party of preachers in Pilsen who would have promoted their interests in the city at the expense of limiting the power of the city council; see: ČAPSKÝ, Město pod vládou kazatelů, 75-101, 129, 135.

16 STRNAD, Listár̆ a listinár̆ II, 147-148. 
the town of Pilsen recognized Matthias Corvinus as its defender and bound itself to be obedient to his instructions. ${ }^{17}$

Already on 20 March 1466, Pope Paul II from Rome also urged the town of České Budějovice to fall away from the heretical king and as an example gave them "our dear Pilsen". ${ }^{18}$ It did not happen and Poděbrady's dedicated burgomaster Ondřej Puklice and his clique for the moment were able to dampen efforts to obey the exhortations of the Roman Curia. ${ }^{19}$ But internal opposition centred around German burghers, led by councillor Mikuláš Raubenhaupt, was growing stronger and waiting for a suitable opportunity to reverse the situation in the city for its own benefit and to stop the trend when control began to pass more and more clearly into Czech hands. Their dissatisfaction culminated when the councillors headed by Ondrej Puklice a year later concealed from the inhabitants of České Budějovice the papal bull which excommunicated the king. Even in České Budějovice, the clergy was supposed to play an important role in the coup, and although the parish priest Ondrej himself hesitated at first, he later allowed the conspirators to meet in the spaces of the parish presbytery. On Sunday 24 May, the preacher Václav Mond ${ }^{20}$ read in the parish church of St Nicholas the hitherto classified bull of Paul II. After mass, he went to the church of St Procopius in the suburbs and the burgomaster and his clique decided not to allow him back into the town, but this step only exacerbated the situation. A horde of armed rebels attacked Puklice's house on 25 May 1467. The putschists seriously injured the burgomaster and later imprisoned him in the town hall's cellar, where he died six days later. His leading supporters were also interned and were to be subjected to torture and execution. ${ }^{21}$ Within a few days, however, passions had faded, and reports of the surrender of the first castles of the rebellious Catholic nobles that had besieged the royal army had raised fears of retaliation. The murderers justified their actions before the monarch, even pretending that there was no conspiracy and that Ondrej Puklice died in a random skirmish. At the intercession of Jan II of Rožmberk, George of Poděbrady forgave the culprits, because the city declared willing to remain on his side against the rebellious Catholic nobles. ${ }^{22}$

So even Puklice's death did not mean that the city officially joined the Zelená Hora League, although it was repeatedly called to do so by its leader Zdeněk of Šternberk.

17 STRNAD, Listár a listinár II, 151, Nr. 181.

18 The original of the letter has been preserved in Státní okresní archív České Budějovice [State District Archives České Budějovice] (hereinafter SOkA České Budějovice), Archiv města České Budějovice (hereinafter AM of České Budějovice), Listiny 1276-1882, inv. no. 109, sign. I/40.

19 Puklice dominated the trade in fabrics, wine and spices, and bought the villages of Čejkovice, Houžná and Hůrka. In 1464 King George gave him the forest Světlík. He was elected to the city council for the first time in 1441 and sat there with short breaks until the end of his life. Despite this turbulent period, he managed to build an extraordinary position; we can even say that he stood at the top of the social ladder of the then Budějovice. He acquired the village of Vztuhy with its stronghold, and therefore began to use the aristocratic predicate, and later bought several more villages and a courtyard in the suburbs of Budějovice. ERBEN, Ondřej Puklice ze Vstuh, 163-211. PLETZER, Ondřej Puklice ze Vztuh, 9-14.

20 On him, PLETZER, Dr. Václav Mondl z Budějovic, 85-87.

21 His son Jan wrote the Tragoedia Andreae Puklicz Budvicensis. Filius patrcem occisus. The most detailed publication on this topic was prepared by KOVÁR̆, Tragédie Ondřeje Puklice. Ondřej had two sons, the elder Václav and younger Jan, who entered the services of the Rožmberks.

22 In July of that year, Hilarius Litoměřický warned in a letter the people of Budějovice of an army which was being led from the west by the king's son, Prince Henry, with the aim of conquering one of the main centres of the Zelená Hora League, Jindřichův Hradec, and which could besiege Budějovice - STRNAD, Listár̆ a listinár̆ II, 153, Nr. 160. Odpuštění od Jiřího z Poděbrad. ČELAKOVSKÝ, Codex luris Municipalis, 511-512, Nr. 296. 
The people of Budějovice secretly promised the legate Lorenz Roverell that they would fall away from George, but they did not rush; why risk what they wanted, that already achieved by Puklice's murder, their gains seeming assured? They tried to imitate the position of Cheb and closely followed the waiting tactics of Jan II of Rožmberk. The appearance of loyalty to King George was reinforced by repeatedly refusing to allow the people of Sternberk into the city. This provoked bitter complaints from the Zelená Hora League before the Curia, which decided to intervene harshly: on 14 February 1468 the Pope declared an interdict over České Budějovice. ${ }^{23}$

Yet the city openly fell away from King George after Matthias Corvinus had entered the war and had enjoyed military successes in the summer of 1468, the defeat of George of Poděbrady and his removal from the Bohemian throne then seeming to be only a matter of time and it no longer seeming a greater risk to declare for his opponents. The final impetus was the July defeat of the Poděbrady army by the town of Vodñany under Jan of Šternberk. ${ }^{24}$

On 20 August 1468, Rudolf of Rüdesheim (then already the bishop of Wroclaw) and Zdeněk of Šternberka declared in Olomouc that they had accepted the town of České Budějovice into the League which they joined for the defence of the faith. ${ }^{25}$ On 30 August, the end of the interdict was officially declared in the town and accepted into the city with a retinue of 200 riders was the leader of the Zelená Hora League and the most important Bohemian supporter of Corvinus, Zdeněk of Šternberk. ${ }^{26}$ King Matthias could finally include České Budějovice in his camp.

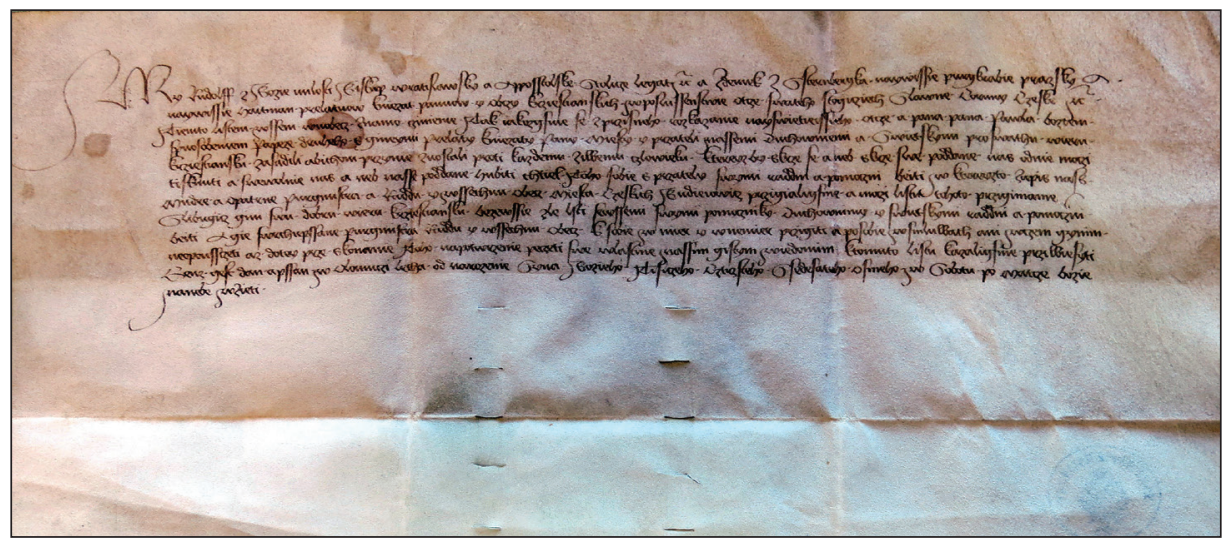

Figure 2: Rudolf of Rüdesheim and Zdeněk of Šternberk's announcement to the town of České Budějovice of its admission to the Zelenohorská; dated 20 August 1468. SOkA České Budějovice, AM České Budějovice, inv. no. 111, sign. II42.

23 The most synoptic treatment of this theme so far was brought by PLETZER, České Budějovice za Matyáše Korvína, 17-56, on the interdict p. 22. The parish priest Ondřej strictly adhered to it and did not allow the burial of the dead, who were therefore buried in the hospital church of St Wenceslas.

24 Jan's letter to his father from 22 July 1468, ČORNEJ, Království dvojího lidu, 179-181, Nr. 83.

25 Original declaration of Rudolf of Rüdesheim and Zdeněk of Šternberk at SOkA České Budějovice, AM České Budějovice, inv. no. 111, sign. II/42.

26 On the abolition of the interdict over České Budějovice, see: SOkA České Budějovice, AM České Budějovice, Codex diplomaticus Budwecensis, 53; PLETZER, České Budějovice za Matyáše Korvína, 24. 
However, a bigger and longer-term problem for Matthias's interests was the attitude of the most populous of the Catholic cities still subject to the Bohemian king - Cheb. If the economic motivation or at least a significant influence of this element influenced the falling away of Pilsen and České Budějovice, the situation was different in the case of Cheb. The town prospered under the stewardship and then the royal government of George of Poděbrady: it had received new economic privileges; the royal efforts to intervene in the self-government were minimal; and the town was mentioned as a venue for important congresses with imperial princes. ${ }^{27}$ The prestige and the material gains and foreign political and trade contacts grew. Here, too, was a strong man who had stood at the helm of urban policy for several decades and who owned extensive property - Kašpar Juncker - but there was no strong opposition group to strive to eliminate him. The town was internally fully stabilized and the wealthiest urban families - besides the Junckers, also the Ruduschs, the Pachmanns, the Püchelbergers also achieved a remarkable symbiosis; the king did not prefer any narrow group or particular individuals. There was also an absence of the element of national disputes: the city was predominantly German and nothing threatened this position. Falling away from King George did not promise any economic gain and the community saw only unpleasant complications in submission to Matthias Corvinus. ${ }^{28}$

A ruler wishing to conquer this city by pressure or direct military force had to take into account that Cheb is not only a town but also controls a vast area where at the end of the fourteenth century it had clearly defeated the local nobility; it was not in error to speak of a Cheb city state, able even without extreme strain to put up nearly 3,000 soldiers, and which in addition, anticipating the impending conflict in Bohemia, had invested considerable sums in equipment. ${ }^{29}$

However, Cheb sent its messengers to the meeting of the Zelená Hora League in Wroclaw in 1467, where both papal legates for Central Europe were present - Laurentius Roverella and Rudolf of Rüdesheim. Nevertheless, they did not succeed with their arguments and the Curia acted even faster than in the case of České Budějovice. In December 1467, the interdict came into effect. Regardless of the position of Pilsen and České Budějovice, Cheb persisted in its neutrality and for it Corvinus was only the ruler of a foreign state leading a war in Moravia and it had not yet been forced to adopt any clear position on that; the interdict was for the time being only a form of punishment for refusing to announce hostilities towards George of Poděbrady, not for refusing allegiance to Matthias Corvinus. At the same time, the Hungarian king announced to the town on 8 April 1468 that he was taking over the protection of Catholics in the Bohemian Crown. ${ }^{30}$ However, Cheb felt no need to respond to this statement.

Nonetheless, this was to change very soon after. On 3 May 1469, Matthias Corvinus was declared Bohemian king by the representatives of the Zelená Hora League in the presence of the Moravian, Silesian and Lusatian Catholic estates in Olomouc's cathedral of St Wencelsas. The ceremonial act was also watched by the representatives of Pilsen

27 THIEME - TRESP, Eger 1459.

28 KUBŮ, Chebský městský stát, 84-85.

29 Státní okresní archiv Cheb [State District Archives Cheb] (hereinafter SOkA Cheb), fund I, book Nr. 2447, p. 43. At the end of 1465, he bought in Nuremburg 203 rifles and 52 harquebuses for almost 200 Rhinish guldens and furthermore 100 helmets - iron hats for 84 guldens. They were intended mainly for the town Landeswehr, whose captain (hejtman) was Oto of Sparneck.

30 Matthew's Letter of 8 April 1468 - original in: SOkA Cheb, fasc. 4, B/69. 
and České Budějovice. ${ }^{31}$ Pilsen had undoubtedly already negotiated with Corvinus in the previous weeks and it was not by chance that immediately after being declared Bohemian king Matthias confirmed for the town its existing privileges, especially then the golden bull of Emperor Sigismund of 1434, which made Pilsen one of the most privileged towns of the kingdom. ${ }^{32}$ In a special deed, he then both donated to the town a magistrate, which the town gladly fell upon because Ondrášek Oremus had joined his enemies, and granted the community the right to freely choose from his centre the magistrate. ${ }^{33}$

The Pilsen city council thus showed more foresight than its colleagues in Wroclaw, who on the contrary considered the gain from the previous periods in the form of the office of captain (hejtman) of the Duchy of Wroclaw to be certain and were in this way very unpleasantly surprised after the arrival of Corvinus. ${ }^{34}$ České Budějovice did not immediately benefit and on the contrary had to undertake to accept the garrison of Matthias.

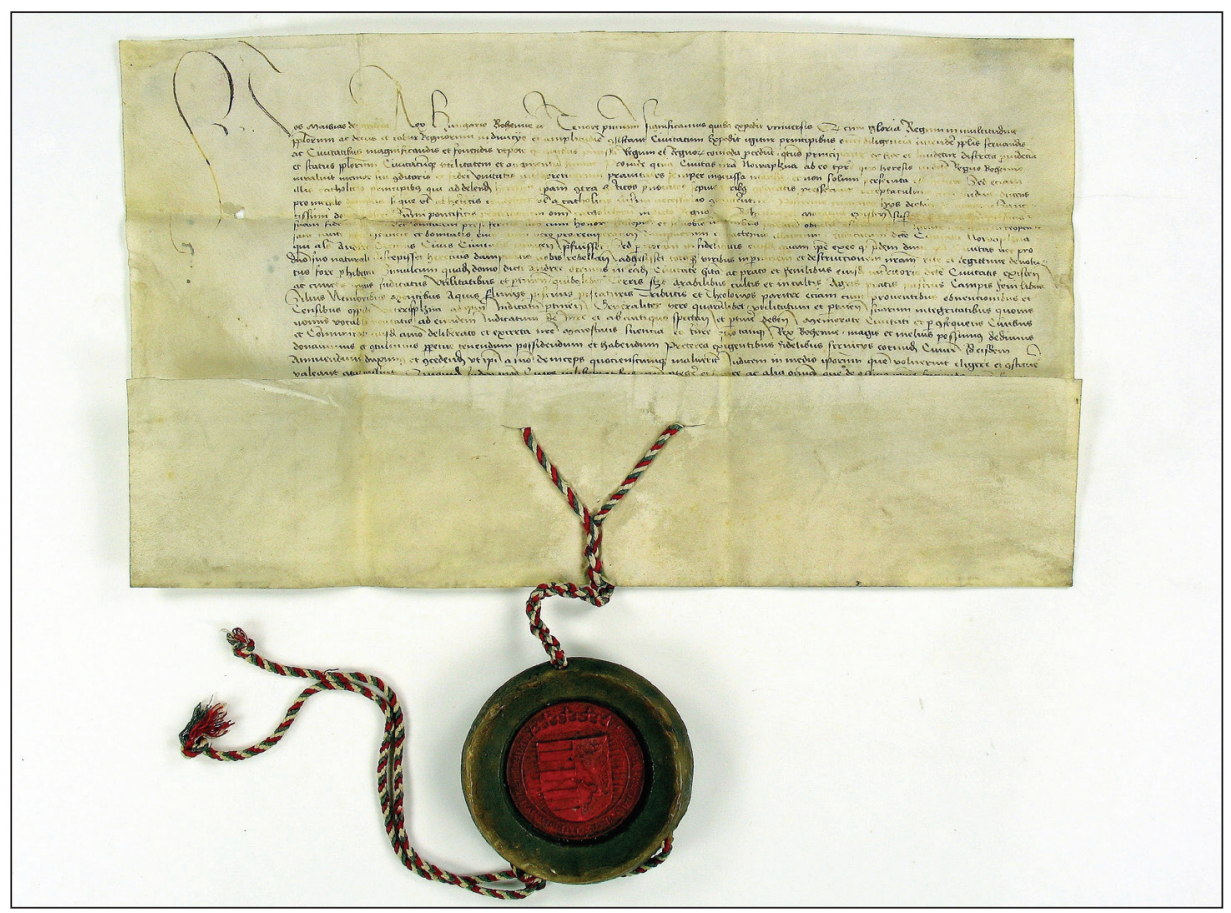

Figure 3: King Matthias donates a village reeve's house; dated 1 May 1469. AM Plzeň, AMP, Listiny, sign. I 190, inv. no. 76.

31 PALACKÝ, Urkundliche Beiträge zur Geschichte, 577, Nr. 482.

32 STRNAD, Listár̆ a listinár II, 185, Nr. 161.

33 The original is in the Archive of the Town of Pilsen: AM Plzně, AMP, Listiny, sign. I 190, inv. no. 76. See appendix Nr. 1, edition of STRNAD, Listár̆ a listinár II, 185, Nr. 161. The deed is dated 1 May 1469 (although Matthias uses the title Bohemian king here and had the small Bohemian-Hungarian secret seal hung here). KALOUS, Matyáš Korvín, 367, note 14 defends the position that it was not a mistake in the dating but a "later writing of an earlier negotiation".

34 ČERNÝ, Zklamané naděje, 187-194. On that, see also: ČAPSKÝ, Hejtmanský úrad, 77-102. 
Corvinus considered himself also the lord of Cheb and in June the Bohemian Hofmeister appointed by him, Bohuslav of Švamberk, with an introductory letter of the legates Lorenz of Ferrara and Rudolf of Lavanta addressed the burgomaster and the councillors with the demand that the town serve Matthias Corvinus its mandatory tribute, the promise of obedience. Cheb refused and based this refusal not on the fact that it still recognized the heretic Poděbrady as its king; it was willing to renounce that, but did not consider the only alternative in such a case to be submission to Corvinus. The councillors very cleverly argued that Cheb was an imperial city by an imperial pledge and, even from a religious point of view, did not belong to the Prague Archdiocese, but to the Bishop of Regensburg, so should not be subject to an interdict. However, they failed with this tactic, and as the ban on worship was now observed and very unpleasantly affected the Cheb residents, the city council decided to partially retreat. When Cheb renounced George of Poděbrady on 17 January 1470, the interdict, announced in 1467, was conditionally discontinued.

However, the city continued to oppose Corvinus, still refusing to recognize him as Bohemian king and as a result its pledge lord. After a repetition of the request by Corvinus's officials, the people of Cheb responded with a small box - they were not obliged to pay any tribute to him, because Matthias had not yet been crowned King of Bohemia nor did he actually rule in Bohemia! The town sought support from Duke Albrecht of Brandenburg, through whom they wanted to acquire imperial patronage, and even the imperial diet was to help Cheb against the pressure of the Curia. Albrecht suggested to the margrave that in this situation the Emperor should be considered the Supreme Lord of Cheb again, which would be much more useful than leaving the town and territory of Cheb to the King of Hungary.

The Cheb emissaries Franz Juncker and Prokop Voidersreuther argued that the people of Cheb always willingly listened to the words of their holiest father the Pope as loyal children of the Holy Church, but that according to the pledge deed they were subject only to the crowned and recognized king of the Czech lands: that when such a good Christian were to arise in Bohemia, they would gladly recognize him. ${ }^{35}$ But the Curia insisted uncompromisingly on Cheb's submission to Corvinus. The appeal to the Emperor and the Empire's position lost any chance of success when in 1472 the Emperor openly acknowledged Matthias as King of Bohemia. ${ }^{36}$ Cheb, in its resistance, could no longer be shielded by this authority, and for the promise of abolishing the interdict was finally willing to pay tribute to the king. Corvinus came out of the longstanding dispute as a winner, mainly due to pressure from the Curia. However, as further developments have shown, the city's rulers understood their move as a formal act, now betting on passive resistance, and were prepared by a delaying tactic to dampen his real impact on the town.

\section{What did Corvinus's recognition mean for the town?}

It can be assumed that the westernmost European cities in his power would be considered by the king primarily as strategic points, important bases where he could

35 On the imperial diet in Regensburg in June 1471, where in Corvinus's name also members of the Zelena Hora League appeared, namely Bohuslav of Švamberk and Lord Dobrohost - BACHMANN, Urkundliche Nachträge, 155, Nr. 139. Abschrift im StadA Eger im SOkA Cheb (Sign. Archiv města Cheb (hereinafter AM Cheb), Box 4, fasc. 4 B 70/26), Pap. (15. Jh.); HOLTZ, Regesten Kaiser Friedrichs III, 297, Nr. 676.

36 CHMEL, Monumenta Habsburgica, 19-27. NEHRING, Matthias Corvinus, 58. 
place his garrisons, the cost of maintaining which would sooner or later be transferred to the municipalities. Furthermore, information would there be gathered on the situations in enemy territories and on the activities of its opponents, and the cities would also serve as venues for the congresses of his Bohemian adherents and would utilise their human and economic resources to the maximum in the interests of the king, although the tax revenues these cities would contribute to his budget would in fact be just a drop in the ocean. It was also expected that city officials would be required to attend convened congresses and meetings of the Matthias Party in Bohemia (we have evidence that he sent them directly to them) ${ }^{37}$ and some of them would be called to his court were he to be residing in the neighbouring constituent lands of the Bohemian Crown. What was the real status, how much could Matthias realize these ideas and how did the towns themselves treat him?

We will first pay attention to Pilsen. As opposed to České Budějovice, Pilsen retained a greater degree of internal autonomy, leaning on the bull of Emperor Sigismund confirmed by King Matthias (the town still submitted in 1474 its copy in the presence of the main Bohemian land officials of Corvinus, Matthias perhaps with this step alerting them that they were violating privileges they had promised to respect $)^{38}$ that provided the town with a number of economic privileges including the limiting of the royal financial demands. Moreover, Pilsen also enjoyed a certain form of the protection of the Roman Curia (including the repeated granting of the right of indulgence not only to the parish church in Pilsen, but also to other churches). Curial protection against the Utraquist king, however, did not mean protection against the Catholic king; Pilsen fortunately was not as strongly affected as its Silesian colleague, Wroclaw. ${ }^{39}$

In addition to confirming all existing privileges immediately after his declaration as the Bohemian king, Matthias very favourably benefited the city when he gave it a special charter to his magistrate, because Ondrášek Oremus had joined his enemies, and granted the village the freedom to choose from his centre. However, as it turned out, even Matthias's privilege did not definitively ensure this important gain for the city; the Pilsen councillors had to face restitution attempts at the land diet in 1474 and the entire dispute was finally ended only by monetary compensation paid to Oremus in 1480.40

During the reign of Corvinus, the names of the following townspeople appeared most frequently in the post of councillors: burgomaster Jakub Žatecký, Vávra Pšenička, Prokop Sviňák, Ondřej Němeček, Jan Chrt, Prokop Sviňák, Přech the maltster, Ondřej Hořovský, Jan Tomášek, Šimon Blažkův, Vavřinec Pekař, Václav Homole, Jíra Mečír.,

37 See Šternberk's letter from January 1475, where he states, PALACKÝ, Archív český IV, 82, Nr. 31. Corvinus's letter printed in PALACKÝ, Archív český IV, 52, Nr. 12.

38 STRNAD, Listár̆ a listinár̆ II, 154-155, Nr. 174 and 184-186, Nr. 221-222. The legate Rudolf pardoned the Pilsen burghers for taking valuables from the closets of the abbot of the Tepla Monastery when he refused to leave George of Poděbrady.

39 Indulgences to Churches, STRNAD, Listár̆ a listinár II, 184-185, Nr. 220, 221.

40 The original is in the Archive of the Town of Pilsen: AM Plzně, AMP, Listiny, sign. I 190, inv. no. 76. See appendix Nr. 1, edition STRNAD, Listár̆ a listinár II, 185, Nr. 161. The letter dated 1 May 1469 (although Matthias uses the title of Czech King here and had a small Czech-Hungarian secret seal stamped on it), KALOUS, Matyás Korvin, 367, Note 14 defends the position that it was not a mistake in the dating but a "later writing of an earlier negotiation". At the diet in Benešov in 1474, Ondráček Oremus demanded that the people of Pilsen return the reeve's house and other estates, but "they did not wait for the judgment, the instructions of the land directors, and left Benešov; therefore they are ordered not to use any payments and benefits resulting from these assets and to defend themselves at the nearest diet" - Listár královského města Plzně (STRNAD, Listár a listinár II), 177, Nr. 210. 
Zdeněk Lukavice, Jan Panoška (until 1470), and the magistrate Mikuláš Ulraich. The city council was dominated mainly by the representatives of the richest trades in the city - cloth makers, butchers and maltsters - who were also patrons of the three largest altars in the dean's church of St Bartholomew. ${ }^{41}$ Since Corvinus left the office of under-chamberlain unoccupied, Zdeněk of Šternberk confirmed the council under the title of Matthias's supreme hejtman (governor), and he might have claimed this power at least occasionally as the king's newly established hofrychtér (Hof-magistrate), as suggested, moreover, by his behaviour in the second half of the 1470 s.

The most influential person in the city was the former councillor Jan Panoška, also known as Laštovice, whom King Matthias named the hofrychtér (Hof-magistrate) of the Bohemian royal towns in 1470; it represented an instance to whom it was possible to appeal from the town courts or directly execute judicial power in affairs of importance exclusively for the king or in decisions laid aside by the town courts for their complexity. However, for independent judgement he handed over his own dispute over a meadow with the family of the Muchovkýs to the Pilsen town court, which found fully for him. ${ }^{42}$ Jan's real authority was limited to only three towns in Bohemia (the rest respected Poděbrady's hofrychtéř (Hof-magistrate) Samuel of Hrádek or Later Vladislav Jan of Radeč) and moreover Cheb refused to recognize Corvinus as Bohemian king for two more years, let alone an official appointed by him. In times of ceasefire, the city did not hesitate to address the current adversary of his master Vladislav of Jagiellon and Cheb about the imprisoned Pilsen burgher Jan Kulper to entrust the decision to the chamber court. Although Jan Panoška demanded considerable money from the town, he was not able to effectively intervene and help the Pilsen Town Council in Cheb. ${ }^{43}$ Nevertheless, he stayed in the office of hofrychtér (Hof-magistrate) until his death in 1477. He repeatedly and, it can be judged, even relatively regularly informed King Matthias about the situation in the towns and maintained regular correspondence with Zdeněk of Sternberg (whom even in April 1471 urged him to convince King Matthias for the fastest possible arrival in Bohemia). ${ }^{44} \mathrm{He}$ was considered a very knowledgeable person throughout Corvinus's side in Bohemia, the king repeatedly sent his instructions through him, and West Bohemian Catholic nobles asked Panoška about the news at Matthias's court. ${ }^{45}$ Evidently, King Matthias was pleased with his services, which is clearly demonstrated by Panoška's ennoblement - Corvinus's official named himself in

41 The archival collection that would document the composition and change of the town council is unfortunately missing; we have to make do with the data from the charters, testimonies in sales and tax obligations and the municipal judiciary. See: AM Plzně, Kniha soudní stranou usnesení majetnosti počínají od roku 1454 až po rok 1484, inv. no. 147; AM Plzně, Kniha testamentů, inv. no. 223. From the literature on that, see: BURKOŇOVÁ, Vztah královské politiky Jiřiho z Poděbrad, 368; e.g. the clothmakers' guild was connected with the specific altar of St Peter at St Bartholomew's church.

42 On the dispute over the meadow bought from Jan Muchek, see: STRNAD, Listár̆ a listinár II, 166-167, Nr. 192.

43 STRNAD, Listár̆ a listinár̆ II, 179, Nr. 213.

44 PALACKÝ, Archív český V, 317. "And go advise HRM that it is time to come to the land". He is titled in the letter as Jan Laštovice of Pilsen, supreme hofmagistrate over the flies (!) of the Hungarian king; omitting the title of Bohemian king is remarkable.

45 PALACKÝ, Archív český IV, 152-153: Writing of various persons in 1471-1490: 20 January 1477: Jindřich of Hradec writes to Bohuslav of Švamberk and informs him about the complaint of priest Hynek about Mr Petr. And he asks for news from King Matthias sent by the Pilsen hofmagistrate. In reply Bohuslav of Švamberk informs that King Matthias wishes to cancel the ceasefire and the covenant with the Moravian lords. He also mentions that Mr Dobrohost of Ronšperk and the lords of Pilsen and Budějovice will come to visit him and then inform Jindrich of Hradec of what they agreed on. 
the deeds as the notorious squire Jan of Pilsen, the royal hofrychtér (Hof-magistrate). ${ }^{46}$ After becoming a noble, Jan apparently began to act haughtily towards the Pilsen populace and intervened in the authority of the town council. A particularly sensitive question was his salary, which the town was to pay him instead of the sovereign, and this was logically resisted and it was argued that the office occupied by Panoška was not municipal but land, and should therefore be paid by the monarch. Evidently John's demands were very extensive, but Corvinus moved them to the town, later to reimburse these expenses and help the city council to fast pay off their debts. It was only a promise. The tension between Panoška and the city council reached such a level that the burgomaster and the councillors threatened to resist his pressure by armed force. Considering the lack of royal units in the city, that force was substantially closer than the monarch's power. The dispute was at least temporarily settled thanks to Vok of Rožmberk, and soon Panoška died. The possibility cannot be ruled out that his early natural death protected Panoška from a worse end. There was no news preserved that King Matthias would have filled his office with a new person. ${ }^{47}$

Panoška had a significant interest in the fact that King Matthias could use Pilsen as a spy centre. ${ }^{48}$ Communication between Pilsen, Budejovice and Cheb, however, to their detriment lacked wider coordination, and the search for a common approach in political issues was lacking. Individual city councils chose their own strategy and Jan Panoška kept the distribution of a series of pieces of information from Mathias's court in his own hands and rarely used city offices for it. 49

The town Pilsen also served King Matthias as a venue for his party's congress, although in this respect he preferred České Budějovice, which, thanks to his own military garrison, he held more firmly in his hands. The most important gathering convened at the instigation of the ruler, on 12 April 1474, was a congress of the states of three West Bohemian regions - Pilsen, Prácheň and Podbrdy. Zdeněk of Šternberk and leading nobles from Matthias's side were present, but only Pilsen is mentioned from the royal towns. ${ }^{50}$

46 PALACKÝ, Archív český V, 316-317, STRNAD, Listár̆ a listinár̆ II - 4 January 1474, p. 117, Nr. 210; 26 October and 29 December 1476, p. 192, Nr. 225 and 25 August 1477, p. 198, Nr. 232.

47 For the settlement of the dispute between Panoška and the city council see the letter of the Zvíkov burgrave Linhart to Had from 5 August 1477 - PALACKÝ, Archív český IX, 20-21, Nr. 44. For the promise of helping the city out of debt, see note 50. A comparison is offered with Mathias's leading Wroclaw supporter Heinz Domping, whose position seemed unshakable. However, just two months after Corvinus's death, he was imprisoned by the city council, accused of betraying city interests, of usurping powers, and of trying to remove the city council from the management of the city. In July of the same year he was beheaded and his body subsequently quartered - KUROWSKI, Heinz Dompnig; RADEK, Vratislavský měštan Heinz Domping, 123-136.

48 On 2 April 1471: Jan Laštovice of Pilsen informs Zdeněk of Šternberk that Castle Loket is besieged by Saxon princes and warns that the arrival of King Matthias Corvinus is necessary. Jan mentions talks with Pilsen lords about possible help. PALACKÝ, Archív český V, 316-317. It was from Pilsen that a letter was sent out in which the early death of King George was prophesied (withdrawn that he will not eat red eggs any more).

49 On the wider communication of the group of cities generally, see: KREUTZ, Ständebunde und Städtendenz (Städtebünde und Städtenetz), 375-379; for an overall view of the latest historiography, see: ČAPSKÝ, Komunikace ve středověkém městě, 15-18. On the role of city offices as communication centres, see: VOJTíŠKOVÁ, Středověké a raně novověké městské kanceláře, 85-93.

50 PALACKÝ, Archív český IV, 476-478: Akta veřejná i sněmovní v království Českém, r. 1473: Zápis ze sjezdu krajů Plzeňského, Prácheňského a Podbrdského z roku 1474. 


\section{Spiritual life}

However, a more important role in providing information not only from the West Bohemian region, but from all over Bohemia, was that Pilsen continued to be the centre of the Catholic Church administration. Until 1478, the aforementioned metropolitan chapter was housed in the city, and at the sedevacantism of the archbishop's seat it became the supreme body of the Catholic Church administration in the country. After the death of the famous administrator Hilarius Litoměřický in 1469 his place was taken first by Hanuš of Kolovraty and later by Václav of Krumlov. ${ }^{51}$ Also, the nominally highest spiritual dignitaries for the Pilsen region, the Pilsen archdeacons, were always chosen from among the Metropolitan canons at that time.

The former influence of the Order of Teutonic Knights on who held the Pilsen parish was already a thing of the past under the reign of Corvinus and with his consent this post was held by the priest Tomáš (proven to have been in office 1461-1477), administering the largest municipal church, that of St Bartholomew, but also the churches of All Saints, St Nicholas, the spittal church of St Mary Magdalena and the suburban church of St Roch and Anna. ${ }^{52}$

The increased preaching activity was reflected in the increased piety of the upper and middle classes of the city. Pilsen burghers apparently prospered despite the state of war in the country (another thing was the state of the city's treasury, especially after 1476) which in their wills they recognized with rich bequests in favour of the churches and cloisters. ${ }^{53}$ In 1474, the town was witness also to the expensive funeral of the cloth-making master Vít, the costs reaching almost 11 threescore Prague groschen. Yet no will of this time vouchsafes directly to help the ruler in the fight against the Czech heretics or Turks; of his officials only hofrychtéř (Hof-magistrate) Jan was mentioned. Corvinus's actions did not gain great sympathy. ${ }^{54}$

On the other hand, the reconstruction of the dean's church of St Bartholomew took place and the three-nave construction was completed thanks to the favour of the burghers and the donors of the temple included even the Šternberks. This is illustrated by a record from 1472 when Jaroslav of Šternberk, son of Ladislav of Šternberk, was buried in the church in the just completed chapel..$^{55}$

51 On 14 November 1469 he sent a priest, Jan the Minorite, from Pilsen to collect alms, STRNAD, Listár a listinár II, 4, Nr. 188.

52 STRNAD, Listár a listinár II, 4, Nr. 188. In the mentioned dispute with the Minorites. On the attached churches, see: SOUKUP, Katedrála svatého Bartoloměje v Plzni, 86-87.

53 Pilsen was even in need of cash to sell for 200 threescore of Prague groschen to claim 20 threescore a year from all the property of the municipality in the town and around to Liutpold of Nekmír and his sons. STRNAD, Listár a listinár II, 187-190, Nr. 223. The financial difficulties of the city were later mentioned by King Matthias himself with the promise of help - see the letter of Řehoř Klaric to the Krumlov burgrave: PALACKÝ, Archív český IV, 159, Nr. 41, "The king told the people of Pilsen he would help them from all their debts in a short while".

54 See legacies in favour of the parish church, among others in the wills of the burgher Ambrož, Barbora Puškářka or Prokop Reš. AM Plzně, Kniha testamentů, inv. no. 223, sign. 1c24, edition. STRNAD, Listár a listinár II, 166-157, Nr. 175-176, and 192, Nr. 225. Reš bequeathed to the hofmagistrate Jan Panošek with gold an embroidered shawl. The sum for the funeral of Vít the clothmaker includes the cost of wax, cloth for priests and pupils, a requiem mass for ringing, but also for beer - STRNAD, Listár a listinár II, 183.

55 FAIT, Gotika v západních Čechách, 262-263; the method of vaulting construction was "incomprehensibly archaic". Most recently on that, SOUKUP, Katedrála svatého Bartoloměje v Plzni. Church of St Bartholomew - In the 1470 s to 1480 s, the Šternberk Chapel was attached to the south side of the presbytery. 
The Minorite cloister of Our Lady enjoyed great popularity among the burghers of Pilsen, in which the metropolitan chapter itself deposited valuable deeds and jewels. ${ }^{56}$ The friars here also had an influential protector in Krištof of Vitbach, the commissioner of the legate Roverrela, who visited the town in January 1471. A number of the people of Pilsen preferred to go to the cloister church for the sacraments, which provoked a sharp dispute between the parish priest and the friars, which the canon of St Vitus had to decide in March 1471, but he decided in favour of the Minorites. ${ }^{57}$

Thanks to Hilarius of Litoměřice and his successors, the city's pride in Pilsen became the Latin city school, focusing on the teaching of rhetoric and stylistics, which maintained contacts also with the German universities in Leipzig and Cologne, and then extended them in the Jagiellonian period to Vienna and Krakow as well. Graduates of the Pilsen School were even ordained as priests. ${ }^{58}$ One of the first printing houses operated by Mikuláš Bakalář Štetina was also active in Pilsen in this period, which at the instigation of the metropolitan chapter issued in 1476 the Latin diocese Statute of Ernest of Pardubice.

Corvinus did not intervene very significantly in the spiritual administration of the town (again unlike České Budějovice). The exception was the protection that he provided to the provost Jiři from the Premonstratensian cloister in Chotěšov. The cloister was plundered in 1468 by the soldiers of the Zelená Hora League, among which there were also armigers from Pilsen. Yet the city had to respect Matthias's will and grant asylum to the provost, but resisted returning the valuable assets seized from the monastery. The hofrychtér (Hof-magistrate) recovered for him at least the return of some rural estates. ${ }^{59}$

The Jewish community, although faced with verbal criticism due to the presence of the Chapter and the increased number of clerics in the city, was at the time of Matthias's reign satisfied with devoting themselves not only to lending but, above all, to the spice trade and was not significantly constrained by the townspeople. ${ }^{60}$

Not too pleasing for the city was the king's attitude to the local mint. He tried to mint his own coins here in 1469 , but he soon decided to establish an entirely new mint in České Budějovice (see p. 16). While he did not close the one in Pilsen founded by imperial authority, he was not interested in its success, its establishment actually being an intervention into his rights as the Bohemian king. No deed has been preserved by which the king officially ended its activity, but after the beginning of minting in České Budějovice he lost interest in it completely and without royal support and patronage

\footnotetext{
56 ŠVÁB, Nápisy u fresek, 196-197.

57 AM Plzně, Františkáni Plzeň, 208, V/4. On the visit of Commissioners Kryštof and Vitbach - STRNAD, Listár̆ a listinár II, 171, Nr. 201. The dispute between the Minorites and the parish priest Tomáš, STRNAD, Listár a listinár II, 77, Nr. 212.

58 MACEK, Jagellonský věk 3, 231. BĚLOHLÁVEK, Dějiny Plzně, 123-124. An interesting approach to the interpretation of municipal schools in the late medieval city is displayed by SULITKOVÁ, Město, fara a škola, 279-296.

59 PALACKÝ, Archív český IV, 51-55: Zápisy kláštera Chotěšovského: apparently without a date since 1474: the prior at that time living in Pilsen under the protection of Matthias Corvinus informs the Prague Chapter about the crimes of the Můchkový brothers. There is an interesting document associated with it, when the legate's secretary Krištof of Vitbach promises the prior indulgences if he contributes something to fight heretics STRNAD, Listár̆ a listinár II, 171, Nr. 201.
}

60 Jews in Pilsen - ŠPIRKOVÁ, Židovská komunita v Plzni, 9. 
it could not function. There is only one remark that suggests that in 1474 the issues related to its former operation had been resolved. ${ }^{61}$ The activity of the mint, although short lived, has also made its impression in Pilsen toponomastics, its seat designating the name of a corner house on the square: "Na rázu" (At the Mint).

\section{Military garrison}

The first evidence we have of the presence of a military garrison in Pilsen after the town recognized Matthias Corvinus as the Bohemian king is from July 1469 . Zvíkov's burgrave then sent his servant with a request to bring people from the Pilsen garrison and help against the knights Malovecs, who had caused great damage to Matthias's partisans in the surroundings of Milevsko. However, it is not certain whether units were then sent directly by Corvinus. ${ }^{62}$

Pilsen did not rush in its obligation to place a royal garrison in the town, but the townspeople understood it only as a temporary measure and soon had significant problems in supplying the troops; the issue was mainly forage for a large number of horses. We are also informed in this context of the presence of Corvinus's garrisons, because in March 1470 the Pilsen councillors wrote to the magistrates and inhabitants of the villages of Úherec, Šlovice, Nýřany and Týne for them to bring a wagon of hay for the riding of horses every week after Sunday. If they continued to refuse, it would be suspected that they would rather support heretics than the orthodox Pilsen, and in that case the councillors would have to allow the "royal people, who lie with us, to forage you for themselves". ${ }^{63}$ These villages did not belong entirely to the broader urban estate and Pilsen therefore tried to pass part of the cost of maintaining the garrison to the surrounding areas and did not hesitate to use threats. Unfortunately, no reliable source has been preserved on the number of Matthias's soldiers and their commanders, unlike in České Budějovice. They left Pilsen at the latest after the conclusion of a ceasefire in the land in June 1472.

There was no direct threat to the city, so it could meet the plea of the Loket burghers, who feared that they would be besieged by the army of the Meissen margrave Albrecht. ${ }^{64}$ Yet in April 1471 the people of Cheb apologized that they would not be able to come to a meeting convened in Pilsen, even though it was about inhabitants of theirs captured in the town by a knight of Wolfštejn, on the basis that the roads were not safe, although the journey would only have taken a day. ${ }^{65}$

In the long ceasefire of 1474-1477, Corvinus's soldiers already having departed the area, the town managed with its own armigers and the surrounding villages were finally relieved of the obligation to contribute supplies for their maintenance. Unlike České Budějovice and Cheb, Pilsen at that time did not have any protracted open conflict

61 BĚLOHLÁVEK, Dějiny Plzně, 104.

62 PALACKÝ, Archív český XIV, 176, Nr. 1892.

63 PALACKÝ, Archív český IV, 168-169, Nr. 14-17; the text of the challenge was the same in all cases; it is a question whether the threat was a reaction to a failure to respond to previous requests, or whether the city was aware that it required these supplies beyond the usual serfdom of these villages and was trying to use Corvinus's garrison to pressure their neighbours.

64 Zápisy Domažlické, r. 1471, 1480: 6 March 1471 - Dobrohost from Ronšperk declares a ceasefire with Racek from Švamberk and the town of Domažlice. On this occasion, he accepts a truce with Bohuslav of Švamberk, with Břeňek of Ronšperk and the city of Pilsen. On sending an infantry unit to List, see the letter of Jan Laštovice to Zdeněk of Šternberk. Omluva Chebských STRNAD, Listár a listinár II, 170, Nr. 199.

65 AM Plzně, Sbírka opisů [Collection of copies], sign. 16. 
with its neighbours to resolve. The next round of the Bohemian war was instigated by Matthias Corvinus in reaction to Emperor Frederick in 1477 joining with Vladislav Jagiellon and the Pilsen populace not wanting Corvinus as Bohemian king and imperial elector at all. They even at first refused to allow into the town the equestrian unit sent by the king under the guidance of Jan Planknar of Kynšperk, relenting only after they received a direct order to do so from Šternberk's successor to the post of the supreme Bohemian captain (hejtman) Bohuslav of Švamberk. On 5 July, it received a direct rebuke for its position from Matthias Corvinus. In a letter written in Czech from Buda he expressed great displeasure to the people of Pilsen over the fact that they "could take such boldness that they should respect our servant more than be allowed to value the master of their hereditary command". He reminded them how he had assisted in the past and instructed the people he now sent to accept no excuses or delays from the city: "we therefore demand of you all diligence, and command according to the duty to which you are obliged to your hereditary master". ${ }^{66}$ It would not have to worry about damage; on the contrary his soldiers would faithfully protect his city in the coming battles.

Pilsen backtracked; Corvinus's commander Jan Planknar and his men entered the town and his title "supreme hejtman (captain) in Pilsen and Budějovice" made it clear that at least in military matters he felt superior to the town councils. He indisputably appears as a capable warrior; he first entirely destroyed a foraging unit of 400 riders, who were sent to the surroundings of the town by the commander of the army Vladislav Burian of Gutštejn, and then on 28 March he defeated Burian himself at Chotěšov, who drew his people to help him. It was an unexpectedly cruel defeat: Vladislav's army left behind on the battlefield over 400 dead, the sources speak of 800 captured, whom the victors took to Pilsen, and among the prisoners were four members of the aristocracy and 16 knights. ${ }^{67}$ Shortly afterwards, Planknar received a letter with information that his lord was preparing to sign a peace treaty in Brno, but after the report of the victory near Pilsen King Matthias withdrew from the prepared treaty and called on Planknar to continue in the fight. ${ }^{68} \mathrm{He}$ even renounced hostilities to the renegade town of Cheb, but the surrounding Catholic aristocracy did not support him, and at the end of the summer Pilsen and České Budějovice tried to get rid of Matthias's soldiers, because they had not been paid for by the king and his officials. Part of them actually left the city. ${ }^{69}$ In November, Pilsen officially joined the ceasefire with King Ladislav and Matthias's rule over the town was coming to an end.

On 25 July 1479 Vladislav accepted the tribute of the town of Pilsen as Bohemian king; he promised that its behaviour in the previous years would not be "remembered in a bad way in speech or in act"; he promised not to interfere in the spiritual administration of the town and confirmed all of the previous privileges. ${ }^{70}$ The question of the validity of the Vladislav Act of 1477 , when King Vladislav admitted claims to

66 STRNAD, Listář a listinář II, 197, Nr. 231 and PALACKÝ, Archív český III, 336, Nr. 37. Corvinus even criticised the burghers, that unlike them "Our people and our other needs to defend you of all our subjects were not regretful, we took no damage, we did not seek our benefits (...)."

67 On the defeat of Vladislav's troops near Pilsen ČORNEJ, Království dvojího lidu, 156-158.

68 Corvinus's call to Planknar to continue to war-PALACKÝ, Archív český IV, 59, Nr. 21. Here also the intention to permanently occupy Horažd'ovice.

69 About that letter of Václav Lhotský of Zásmuk to Vok of Rožmberk from June 1478 - PALACKÝ, Archív český $X, 28$.

70 PALACKÝ, Archív český X, 205-206, Nr. 249. 
Pilsen magistrate Ondrej Oremus, arose. The final point was in the next year, 1480, when a compromise acceptable to both sides resolved everything. The municipality of the city of Pilsen retained the reeve, but it paid Ondřej Oremus a financial compensation of 1,200 Hungarian forints. ${ }^{71}$ Only Pilsen's Jews were to remember Matthias's reign as a calm time; for them the Jagiellonian era was unfortunately to bring a series of limitations in the existing areas of business and normal life and in 1503 complete expulsion from the town.

České Budějovice should have felt Corvinus's hand more strongly than Pilsen. The town was popular with Zdeněk of Šternberk; he often stayed there and the town council had to subject itself to his will whether it liked it or not, Zdeněk not having forgotten how it had refused his calls in 1467-1468..$^{72}$ Not even Jan of Rožmberk, according to whom the city had managed its political actions so many times, could help; he himself faced pressure and had to give Šternberk, as a contribution to the war costs, his subject city of Soběslav. ${ }^{73}$ On the contrary, from him and his officials were sent repeated reproaches to České Budějovice for the wrongs which precisely the royal soldiers encamped in České Budějovice did to his serfs. The route to Prague, on which communication headed through Vodňany and Písek to Pilsen was broken, was now hostile territory for the Budějovice merchants, whereas crucial importance for Šternberk and his allies from the ranks of the original Zelená Hora League was assumed by the routes leading to Nové Hrady and Vitoraz, and to Třeboň and further to Vienna. We therefore first devote attention to the royal garrison in the town.

A unit of riders had already been placed in Budějovice in 1468, brought there after the victory over Poděbrady's forces near Vodňany by Šternberk's captain (hejtman) Jindřich of Dobrovítov. They were at most 200 armigers. At the request of Jan of Rožmberk, these people participated in June 1469 in the campaign for the stronghold Dubno against Jindřich Roubík of Hlavatece. ${ }^{74}$ However, the České Budějovice population was soon to be confronted by much more numerous forces.

As a consequence of the Olomouc oath of May 1469, the town was to accept Matthias's garrison and it was clear that the existing garrison of Šternberk would be replaced by a new, even larger contingent. In June, King George cancelled the ceasefire with Matthias Corvinus, and therefore shortly afterwards a unit of crusaders (mercenaries amassed in 1467-1468 on German territory under the pretext of a new crusade against heretical Bohemia) ${ }^{75}$ was placed in České Budějovice, led by the English aristocrat John Rod de Winshorne. Nevertheless, with his behaviour he aroused such resistance in the town and the wider surroundings that on another excursion from the town with an unspecified number of soldiers Rod was in October 1469 attacked by a group of České Budějovice armigers, who were assisted even by the people of Jan of Rožmberk. The attacked escaped without loss of life, but were deprived of money

71 Award of the reeve's post to Oremus, STRNAD, Listár a listinár II, 199-200, Nr. 233. The final full stop to the dispute over the reeve's post - STRNAD, Listár a listinár II, 208-210, Nr. 252.

72 STRNAD, Listár a listinár II, 165, Nr. 189. On 14 January 1470 he was in town with his retinue and from there he wrote a letter in German to Pilsen.

73 On the situation of Jan II of Rožmberk in the most detail, see: ŠıMŮNEK, Správní systém, 82-83, 370-371.

74 About their campaign to April PALACKÝ, Archív český VII, 358-359, Nr. 334.

75 On their activities on Czech territory KUMPERA, Dějiny západních Čech I, 158-160 and JÁNSKÝ, Kronika česko-bavorské hranice IV, 68-70. 
and equipment. This incident is clear evidence that the crusader commander was not the master of the city. He did not respond with arrests and exemplary punishments, but asked for the intervention of the city council and its intervention with Jan of Rožmberk in the matter of returning the stolen property. The councillors themselves, notwithstanding their lack of sympathy for Jan Rod, understood that the event was "a great shame on the lord majesty and us" and they turned to the Rožmberk governors for remedy. Surprisingly, the whole dispute was settled amicably by Zdeněk of Šternberk as the Supreme Captain (Hejtman) of Bohemia. ${ }^{76}$

It was clear that this Crusader troop was not enough to do the job. In January 1470 John Rod and his men left České Budějovice, and Jan of Šternberk therefore placed in the city a garrison of 600 riders, later to add 400 more. ${ }^{77}$ These were mostly Polish mercenaries, but they were commanded by the Czech captain (hejtman) Jan Bílý. It was soon clear that even this garrison would cause the town large problems. The soldiers were paid irregularly and moreover in money coined in the Ceské Budějovice mint, the acceptance of which Jan of Rožmberk had forbidden to his subjects. ${ }^{78}$ The issues with supplying such a large number of armigers led to repeated supply excursions into the surrounding areas, in which the Poles did not distinguish between the estates of supporters of King George and Matthias's adherents. Jan of Rožmberk in particular bitterly complained about their behaviour and soon it was as if the situation of October 1469 was repeating itself, but this time without the involvement of the burghers of České Budějovice and their people. ${ }^{79}$ When the commander of the Poles, Jan Bílý of Stračkov, went with several people to Český Krumlov to discuss Rožmberk's complaint, capture and imprisonment awaited them. As a consequence of the lawsuit regarding the behaviour of the Polish garrison, which reached even Matthias's court, a new royal captain (hejtman), Markvart of Rakovice, the then commander in Jindrichův Hradec, was sent to České Budějovice. ${ }^{80}$ Jan Bílý was released after the king's intervention and returned to Budějovice as Markvart's assistant. The new captain (hejtman) was shocked at the state of the garrison, which was unable to be deployed to fight in the field and could not even help in the siege of a nearby stronghold of knights loyal to Poděbrady: "the journeymen do not have enough money and have pawned their armour and are in debt to good people and if we were to ride, we would have to go naked and without weapons". It is no wonder these mercenaries were not shown

76 On that letter to the České Budějovice burgrave in Krumlov PALACKÝ, Archív český XXI, 380-381, Nr. 334. On the English mercenaries, see: ŠIMEČEK, Angličtí křižáci, 14. It is very unlikely that John Rod would have been of the status of a count, even if he claimed it himself.

77 PALACKÝ, Urkundliche Beiträge zur Geschichte Böhmens un seiner Nachbärlander im Zeitalters Georg von Podiebrad (1450-1471), Wien 1860, 615, Nr. 605.

78 PALACKÝ, Archív český V, 315-316.

79 The damage caused by the Polish mercenaries from Budejovice was complained about even by the governor of Třeboň, John of Kozi; see: PALACKÝ, Archív český VII, 392-393, Nr. 357. Jan of Rožmberk himself made a complaint about Zdeněk of Šternberk for his behaviour - PALACKÝ, Archív český V, 313-314, Nr. 4. On 11 March 1471 he literally wrote: "Poles from Budějovice are unchristianly destroying my estates" and criticised Jan Bílý, accusing that when Bílý's soldiers came to Trhové Sviny they took not only forage but that "what they found, they took". Rožmberk turned with his complaint about the Polish garrison in Budějovice even to King Matthias himself - Státní oblastní archiv Třeboň [State Regional Archives in Třeboň] (hereinafter SOA Třeboň), Historica, inv. no. 3044, sign. 2469.

80 Markvart is titled the "governor of Budejovice" in the letter to Jan Tluks of Vrábí of 24 March 1471 PALACKÝ, Archív český V, 314-1315, Nr. 5. On the state of the garrison, the letter from Rožmberk - PALACKÝ, Archív český V, 315-316, Nr. 7. 
respect and sympathy in the town. During Markvart's time, the situation improved; he was apparently able to ensure better supplies and was able to speak to the town council with greater authority than Jan Bílý, but his administration did not take on the character of a military dictatorship. Even so, the city council accepted it with great relief when, in July 1472, as a consequence of the conclusion of the ceasefire between Corvinus and Ladislav, the Polish garrison was substantially reduced, a state which was to last until 1477.

The bad situation of Matthias's mercenaries was due in no small part to the failure of a plan from which the king apparently had promised much - the establishment of his own mint in České Budějovice. It was active there from April 1470, in March the king informing Jan of Rožmberk that "we give notice that we are sending our mint master to Budějovice, to coin here and make good and worthy money". Nevertheless, its activity was limited to the minting of small silver coins of a diameter of $15 \mathrm{~mm}$, the relation to the Prague groschen being set at 7:1 and to the Hungarian forint at 280:1. The coin's image was a halved coat of arms, on the right half of which was represented the old Arpád coat-of-arms and on the left the Bohemian lion. Although silver mines were open in the close proximity of the town in Rudolfov in the sixteenth century, it is much more likely that in Corvinus's time in Budějovice the coinage was only from old re-melted coins. The king tried to enforce the acceptance of the Budejovice coins also in the Austrian borderlands, and he also asked the Bishop of Passau and Reinprecht of Walssee to do so in their holdings, claiming that the coin would be equal to the Vienna coin. ${ }^{81}$

Nevertheless, the coins encountered disinterest or direct fear from the merchants and peasants bringing foodstuffs and poultry to the market in Budějovice and it was no different at the markets in the Rožmberk townships. The captain (hejtman) Markvart warned the Rožmberk officials that if Jan's subjects refused to sell goods to the Budejovice garrison's soldiers for the new coins, he would not be able to stop them from taking these needs by force and moreover he would have to address a complaint to King Matthias himself. ${ }^{82}$ Jan of Rožmberk in fact received in May a letter from the king containing a sharp rebuke. ${ }^{83}$ In Soběslav, Šternberk's officials even brutally beat a tavern woman who refused to accept the coins. ${ }^{84}$ The Budějovice coins did not succeed even in the Šternberk-controlled Polná and Vitoraz, and encountered resistance even in Jindřichův Hradec and, to great anger from Matthias, even in Jihlava.

We can only estimate the amount of the production; the Budějovice "Corvinus's" money has been preserved only sporadically, which may not evidence a small number of coins being minted, but more, rather, their recall and re-melting. No clear opinion

81 The original of Corvinus's Czech-written letter has been preserved in the SOA Třeboň, Historica, inv. no. 2909, sign. 2344. On that letter, see note 84 below. On the later mining in Rudolfov, see: HUYER, Die Münzstätte, 123-126.

82 Markvart's letter to the Krumlov burgrave from 24 May 1471, see: PALACKÝ, Archív český V, 322-323, Nr. 17. "The Poles again robbed on the estates of your lord and the people of your lord will be harmed" - The Polish here mentioned are not meant as being on the Jagiellonian side as judged by KALOUS, Matyáš Korvín, 200, but as members of the Polish garrison in České Budějovice.

83 PALACKÝ, Archív český VI, 46, Nr. 3; on the sending of mint masters, Corvinus literally said: "We also ask you again that when the coins that are made as they should be in Budějovice are issued, command his people to take no other coins for goods, because there will be a coin equal with the Viennese for once (...)"; PALACKÝ, Archív český VI, 47, Nr. 4; a letter from 17 May - on the ratio of groschen and Hungarian gold and the complaint that Rosenberk's subjects refuse to accept this coin.

84 On the beating of this woman, see: PALACKÝ, Archív český V, 321, Nr. 15. 
dominates among numismatic experts on when the Budějovice coinage ended; the most frequently presented year is 1471 . This opinion is supported by the fact that the frequent complaints of resistance to this coin and the written admonitions by the king and his officials go quiet in $1471 .{ }^{85}$ In Budějovice, Hungarian forints began to circulate in addition to Bohemian groschen; the city council also quantified values in these currencies several times and in them settled obligations: For example, Jakub the scribe received 45 Hungarian forints from the town council, and in an inheritance settlement we do not hear of the calculation of property, payment of loans or inheritance in "new monies". ${ }^{86}$

We will now pay attention to the representatives of the town administration in the time of Corvinus's reign and their activities. Although Josef Macek states that the captain (hejtman) renewed the town council, the source he gives only speaks of the presence of the royal captain (hejtman) and deputy captain (místohejtman) in Budějovice, not their participation in or execution of the renewal or confirmation of the town council. ${ }^{87}$ Considering the frequent presence in the town of the office of Corvinus's supreme captain (hejtman), it was most likely done by Zdeněk of Šternberk, who repeatedly renewed, for example, the town council in Jihlava, but it is not possible to rule out with certainty even hof-magistrate (hofrychtéř) Jan Panoška, who would only in fact execute such a step with direct support from Šternberk. ${ }^{88}$

Mikuláš Rabenhaupt, the leader of the conspiracy against Puklice, remained the most influential of the burghers of Budějovice. He then remained uninterruptedly on the town council until 1477, several times as the prima; other councillors included his son Matthias Rabenhaupt, Tomáš Fruauf, Mikuláš Pop, Prokop Šitter, Martin Holport, Hanuš Perl, Mikuláš Libovec, Hanuš the barber, Šimek the shooter, Matyáš Krensperk, Zikmund Kutner, Šimon the butcher, Ondřej Khoczehogel, Jan Plobl, and Hanzl the clothmaker, and a position was even maintained by the son-in-law of Puklice Prokop, Štraboch of Vztuchy. Several members of the Klaric family expelled by Puklice were returned and Beneš held the post of magistrate at that time. ${ }^{89}$

Such an influential person in Pilsen as Jan Panoška was did not rise from the ranks of the Budějovice burghers during the time of Corvinus's reign. From 1471, the royal captain (hejtman) also sat in the town, which caused a certain limitation of the municipal self-government in favour of military leadership, although after the ceasefire in 1472 ,

85 On the Mint of České Budějovice, see: NECHANICKÝ, Matyáš Korvín. Further: MILITKÝ, Mincovna Matyáše Korvína, 63.

86 SOkA České Budějovice, AM České Budějovice, inv. no. 114, sign. II/45.

87 MACEK, Jagellonský věk III, 41; with a reference to the renewal of the town council in Budějovice by Corvinus's hejtman PALACKÝ, Archív český XXI, 199, Nr. 40-45; however, this letter does not mention the appointment or any speech of the governors to confirm the city council. Macek also has no evidence to suggest that under the supervision of the governor of Corvinus, the function of the Budějovice municipality was substantially reduced, if not completely liquidated, except that Corvinus addresses solely the burgrave and councillors in the city. However, besides Budějovice, Corvinus acts analogically also in his letters to Cheb, where none of his captains were.

88 KALOUS, Matyáš Korvín a moravská královská města, 100.

89 An overview of the members of the town council was given by ERBEN, Časopis Českého muzea, 244. On the return of the Klarices, see: JANOUŠEK, Rod Klariců, 1-13. 
his interference in the normal operation of the city was minimized, as testified by the activity of the municipal court and the functioning of property affairs. ${ }^{90}$

The Budějovice councillors did not resolve the dispute with the yeoman Petr Stoupenský from Húzná (also from Hužná) through Corvinus's captains (hejtmen), but they turned directly to the sovereign. Stoupenský in 1473 attacked on the public highway a caravan of seven wagons commanded for Budějovice by Hilšar and going to Austria. The town council supported him, but the proud yeoman refused to return the loot; Hilšar was not to have deposited the goods in Budějovice but in Freistadt (Cáhlov), and besides that he himself stayed in Budějovice at Zdeněk of Šternberk's and never heard that Hilšar was to have been in the services of the town. ${ }^{91}$ The people of Budejovice turned directly to the king then procrastinating in Brno and King Matthias personally answered them in a letter written in Czech on 23 March 1473. At his command, the dispute should have been investigated by unnamed nobles, and if they did not reach a clear conclusion, Zdeněk of Šternberk should have the final say. It was not an unfavourable conclusion, because the attitude of the king's supreme Czech captain (hejtman) towards the city had changed considerably since the end of the $1460 \mathrm{~s}$ and although it would be an exaggeration to identify the lord of Šternberk directly as a supporter of the people of Budějovice, he actually helped the town in his conduct also in the following years.92

The town council also managed in 1474 to help the burgher Hanuš Richšler, who had property confiscated in Legnica for suspicion that he belonged to King Vladislav's side. When he proved by a letter from the Budějovice town council that he was their regular citizen, his property was returned to him. ${ }^{93}$

By a special letter addressed to the burgrave and councillors, not to the royal captain (hejtman), King Matthias announced the conclusion of a ceasefire with Vladislav and Poland's Casimir and called on them to send their representatives to the prepared land diet in Prague in January of the next year (1475). ${ }^{94}$

When, however, in a dispute with Knight Racek Kocovský they turned within the actual two governments in Bohemia to the "Prague king", because they expected a more favourable conclusion of the whole dispute than from their lord Matthias, the members of the royal council Vilém of Vrábí, Čeněk of Klinkštejn and Jan of Jenštejn

90 On the activities of the Municipal Court at this time, see: SOkA České Budějovice, Kniha nesporného a sporného soudnictví 1396-1525, inv. no. 1086, sign. D2.

91 On Stoupenský, see: PALACKÝ, Archív český V, 344. Mathias's letter to Budějovice of 23 March 1473, see: PALACKÝ, Archív český VI, 51-52, Nr. 11. Listy Budějovické městské rady: PALACKÝ, Archív český VI, 347-348, Nr. 57. From there we learn that crocks, beer and feather bags were taken.

92 On this letter by Stoupenský to Budějovice of 18 June 1474, in which he promises to submit to the will of Matthias - PALACKÝ, Archív český V, 348, Nr. 58. On Šternberk's changed approach to the town and his direct support of the town in its dispute with Kocovský, see: PALACKÝ, Archív český VI, 126-127 3 - "I stand and will not leave you of Budějovice in the affair of yours against him and so be worthy of you" and PALACKÝ, Archív český VI, 127, Nr. 4 - "against whomever I always want to advise and help you". Moravian cities also turned directly to the sovereign in a similar way repeatedly; see: KALOUS, Matyáš Korvín a moravská města, 118; also here the sovereign mainly turned the matter over for investigation by his officials and entrusted the final decision to one of the significant Moravian aristocrats.

93 The letter of the Wroclaw town council to the burgomaster and councillors of České Budějovice - SOkA České Budějovice, AM České Budějovice, inv. no. 113, sign. II/44.

94 Matthias's letter to Budejovice of 30 November 1474, see: PALACKÝ, Archív český VI, 52, Nr. 12. 
rebuked them, asking by what right they dare to turn to them, being councillors of King Vladislav, not "that one of yours".95

The people of Budějovice probably had no idea how thin was the ice onto which they were moving. As with Pilsen, Matthias considered himself to be their hereditary lord, and to turn, without his knowledge, to a foreign ruler, with whom only a ceasefire but not a peace had been concluded so far, could easily have been considered by Corvinus to have been an interference in his sovereignty. It was a precedent that none of the Moravian or Silesian cities under his rule had ever set.

King Matthias himself became involved in the whole thing, but the city still escaped his fury and everything returned to the usual framework when his supreme steward (hofmeister) Bohuslav of Švamberk took over further negotiations with Budějovice. ${ }^{96}$

The external problems were also reflected in a vigorous approach within the city, which was not surprising when remembering the violence which some burghers holding posts in the council in the 1470 s had committed in 1467 , as proven also by a mention from 1476, when the city council refused Soběslav's request to lend their executioner on the grounds that they themselves needed him in Budějovice. ${ }^{97}$

Yet from 1475 the city became embroiled in the already mentioned protracted private war with the knight Racek Kocovský, lord of the town of Horažd'ovice. An almost nine-year-long conflict arose from an entirely petty dispute over the issuance of a box with 10 threescore of Prague groschen, which Racek's fugitive servant had deposited at the Budějovice town hall. What was interesting about it in this context was the position of Zdeněk of Šternberk, who in the letter to the "wise and cautious burgomaster and council of the town of Budějovice, friends and neighbours" wondered why the city did not address the matter directly to King Matthias with a request for assistance, stating that "you would not have been abandoned by us". ${ }^{8}$ All attempts to settle the dispute and the call for both sides to "not reach for any more power"failed. ${ }^{99}$ The Budějovice burghers listed in detail the growing damage suffered by the violent approach of Kocovský: stolen horses, cattle, weapons and clothing, to which soon were added tributes, burnt subject villages, ransoms from captivity and several killed. ${ }^{100}$

Despite the sad experience of 1469-1472, the town at least for a time accepted with relief that after the commencement of a new round of the war with Ladislav Jagiellon in 1477 King Matthias decided to again place a strong garrison in the town. Racek Kocovský even claimed that the people of Budějovice "wrote to the Hungarian king, their lord, that they want to allow His Majesty's people who will come to the town", but the motive on Matthias's part was not in the first place to help the Budejovice burghers in their fight with their adversary. ${ }^{101}$ The aforementioned commander of Corvinus's Jan Planknar of Kynšperk settled in Pilsen, but entrusted the Budějovice contingent to the equally vigorous captain (hejtman) Václav Lhotský from Zásmuky; also here was the under-captain (podhejtman) Mikuláš Pešík from Bělá. Now, there was truly a significant limitation of the town's self-government. Lhotský's correspondence

95 PALACKÝ, Archív český IV, 86, Nr. 35 and PALACKÝ, Archív český IV, 90.

96 On that, the letters to Bohuslav of Švamberk, PALACKÝ, Archív český IV, 87-88, Nr. 36, 37.

97 HUYER, Zur Geschichte des Stadthauses, 4.

98 Šternberk's letter of 5 January 1475, PALACKÝ, Archív český IV, 84, Nr. 31.

99 On the damage that Racek Kocovský caused to České Budějovice, PALACKÝ, Archív český IV, 73-75, Nr. 18. 100 List of damages calculated in 1479, PALACKÝ, Archív český IV, 93-96, Nr. 46.

101 PALACKÝ, Archív český IV, 90. 
with the well-known warrior Václav Vlček of Čenov, who expressed the conviction that what Lhotský sets, the Budějovice burghers will fulfil - "for I know they are under your captaincy (hejtmanství)" - testifies well to the situation in the city. Another sizeable unit of riders, who were brought here in January 1477 by Jaroslav of Boskovice under the pretext of strengthening the Budějovice and Pilsen garrisons, remained in the town only for several days and only served to capture Bohuslav of Švamberk (see below).

Nevertheless, the events of 1470-1472 were repeated. The mercenaries from the garrison again plundered in the surrounding areas. On 3 January 1478, Lev of Rožmitál wrote from Castle Blatná to the people of Budějovice: "The strange thing is that from the town of your beginnings things always happen against the Christian truce". ${ }^{102}$ Václav Lhotský of Zásmuky strongly opposed the complaint. The royal garrison in České Budějovice was then apparently more numerous; a preserved report speaks of 900 mercenaries. ${ }^{103}$ The city itself was, however, already exhausted and not even this strong a military contingent gave the local populace the feeling of safety from external enemies; after all, their own militia was in conflict in 1478 simultaneously in three different places: near Horažd'ovice, where according to the preserved sources only 40 armigers of České Budějovice took part in the siege ${ }^{104}$ (at least in that the town the benefit could be seen in the presence of Corvinus's mercenaries); practically in sight of the city walls where they had conflicts with the garrison from Castle Hluboká; and with an experienced opponent in the form of the aforementioned Václav Vlček of Čeňkov, who had become the lord of Castle Helfenburk. Although a truce was to be in effect, Vlček did not hesitate to capture several merchants of České Budějovice and even burnt down the town and one subject village. ${ }^{105}$ Matthias's garrison in Budějovice did not show the least willingness to act against Čeňkov, and even though the cavalry units repeatedly left the city, they focused only on "foraging" for their own needs.

The dissatisfaction with such a situation grew in the town and a notional slap on the face of the burghers came when their worst opponent, Racek Kocovský, secretly established contact with King Matthias. His people were to break through the circle of besiegers (among whom, as was already stated, were also people of Budějovice) and take the town! It did not happen; he escaped from the siege, and his estates were confiscated and sold. České Budějovice received a mere 40 Hungarian forints! Unlike some Moravian towns under Corvinus's rule, České Budějovice could only dream of the attribution of real estate, villages or courtyards, although it would have directly offered itself had they been compensated from the real estate of Racek Kocovský. ${ }^{106}$

However, at the end of the summer, Budejovice attempted to get rid of Matthias's soldiers, because they had not been paid on the part of the king and his officials and part of them had truly left the town; Václav Lhotský himself had offered to serve Vok of Rožmberk!107 From the same period is a report placing the executions of ten

102 Rožmitál's letter of 3 January 1478, PALACKÝ, Archív český VI, 159, Nr. 4.

103 PALACKÝ, Archív český VI, 161, Nr. 43.

104 This number is stated in a letter from Hynek of Švamberk with great wonder: "weird that you do not have in this matter, as you should have, and that the trouble all arose for you"-PALACKÝ, Archív český IV, 91, Nr. 41.

105 PALACKÝ, Archív český XXI, 199, Nr. 42.

106 For a detailed account of the damage that Kocovský caused to the city of Budejovice and its subject villages, PALACKÝ, Archív český IV, 93-97. On the gift of the Moravian towns, KALOUS, Matyáš Korvín a moravská města, 111-112. On Corvinus's plan to acquire Horažd'ovice, see his letter to Jan Planknar, note 62.

107 On that, see the letter of Václav Lhotský from Zásmuky to Vok of Rožmberk of June 1478, PALACKÝ, Archív český $X, 28$. 
journeymen who had resisted arrest and fatally injured the magistrate. The traditional notion of the conspiracy of the poor has been abandoned by urban historians and they rather support the opinion that they were in fact undisciplined garrison soldiers. Even so, it is unlikely that the city council would issue an order to execute them without the direct consent of Jan Planknar or at least Václav Lhotský. ${ }^{108}$

So far, attention has been paid to the aspects of administrative power and the military, but what were the ecclesiastical conditions at the time when the town recognized Matthias Corvinus as their lord?

In March 1470, after a long 26 years in office, the parish priest Ondřej Ondřejưv died during his stay in Passau, and his body was transferred to Budějovice and buried in the parish church of St Nicholas. ${ }^{109}$ The Budějovice parish priests then had three vicars and 13 altar boys, in just the parish church itself; the Budějovice presbytery was very lucrative: it had two entire villages, a number of arable courtyards, a group of smaller homesteads in Staré Město and a large courtyard attached to it; therefore several interested parties appeared for the open post. ${ }^{110}$ King Matthias took advantage of the right of patronage belonging to the Bohemian king and with reference to the old recommendation of Hilarius Litoměřický presented to the Budějovice presbytery the priest Dr Václav (apparently meaning Václav Křižanovský) and Jan of Rožmberk, who had turned to him in the same matter. He announced in a letter of 17 March 1470 that he had already made a positive decision on the matter. Another candidate was $\mathrm{Dr}$ Jindřich Erzger, also a friend of Hilarius, who then even visited Budějovice. The city council wanted him, but it did not dare to enter a dispute with the sovereign over it as it had done under the reign of Ladislaus the Posthumous. Jindřich did become the parish priest in the end, but only thanks to the fact that Křižanovský had unexpectedly died (it being a question whether he ever managed to assume the assigned office). ${ }^{111}$

The monastery of Our Lady of the Dominican Order with the large church of the Sacrifice of Our Lady, which was directly incorporated into the town fortifications, also enjoyed considerable importance. In Matthias's times, another recovered from a fire that struck it in 1463 and enjoyed similar popularity with the Budějovice burghers,

108 The event probably occurred in 1478 and was an unwitnessed disturbance of greater magnitude in which the town magistrate or his assistants were fatally injured. The severe punishment was obviously exemplary in order to prevent the recurrence of similar cases. The convicts can hardly be considered the sons of the townspeople, and it is far more likely that they were from the Hungarian army of Matthias Corvinus, who was supposed to protect České Budějovice and who was known to have acted violently. PLETZER, České Budějovice za Matyáše Korvína, 16: "Perhaps, therefore, several members of the Hungarian military garrison violated city law in some way and armed resistance when arrested by the magistrate, which was twice as serious and aggravating as a mass execution sentence".

109 About his death and deposition in the parish church of St Nicholas SOkA České Budějovice, AM České Budějovice, Liber memorabilium decanatus Budvicensus I, f. 127 b. About Zdeněk's death and Corvinus's letter to Jindřich of Rožmberk, PALACKÝ, Archív český VI, 54, Nr. 14.

110 List of the clergy at the church of St Nicholas to 1467 survived in SOkA České Budějovice, Pamětní kniha českobudějovického děkanství, inv. no. 719, sign. V/1. On that, ADÁMEK, Oltářnická beneficia v Českých Budějovicích, 34; a total of 16 people, the parish priest Ondřej, three vicars and 13 altar boys.

111 Corvinus's letter of 17 March 1470, PALACKÝ, Archív český VI, 46, Nr. 3. King Matthias was very sensitive in these matters and he did not even hesitate later in Wroclaw to speak very sharply to the members of the chapter when they dared to oppose him, considering another candidate for the post of bishop of Wroclaw instead of Jan Roth proposed by him - URBAN, Skiczie (Szkice) z dziejów diecezji wroctawskiej, 13. 
and the cloth makers' guild in particular was among the leading adherents. ${ }^{112}$ Just like its "Franciscan colleague" in Pilsen, this cloister also came into conflict with the local parish priest in the affair of providing the lay with the right to confession, absolution and the last anointment. The administrators in Pilsen apparently preferred the parish priest, but the secular power including Matthias's land officials had sympathy for the cloister. ${ }^{113}$ The monastery received significant accolades when it was chosen as the final resting place by Matthias's highest captain (hejtman) in Bohemia Zdeněk of Šternberk. When he died in December 1476 in Vienna's Neustadt, his body was buried in Budějovice's Dominican cloister and the magnificent tombstone made then was still remembered in the eighteenth century. ${ }^{114}$

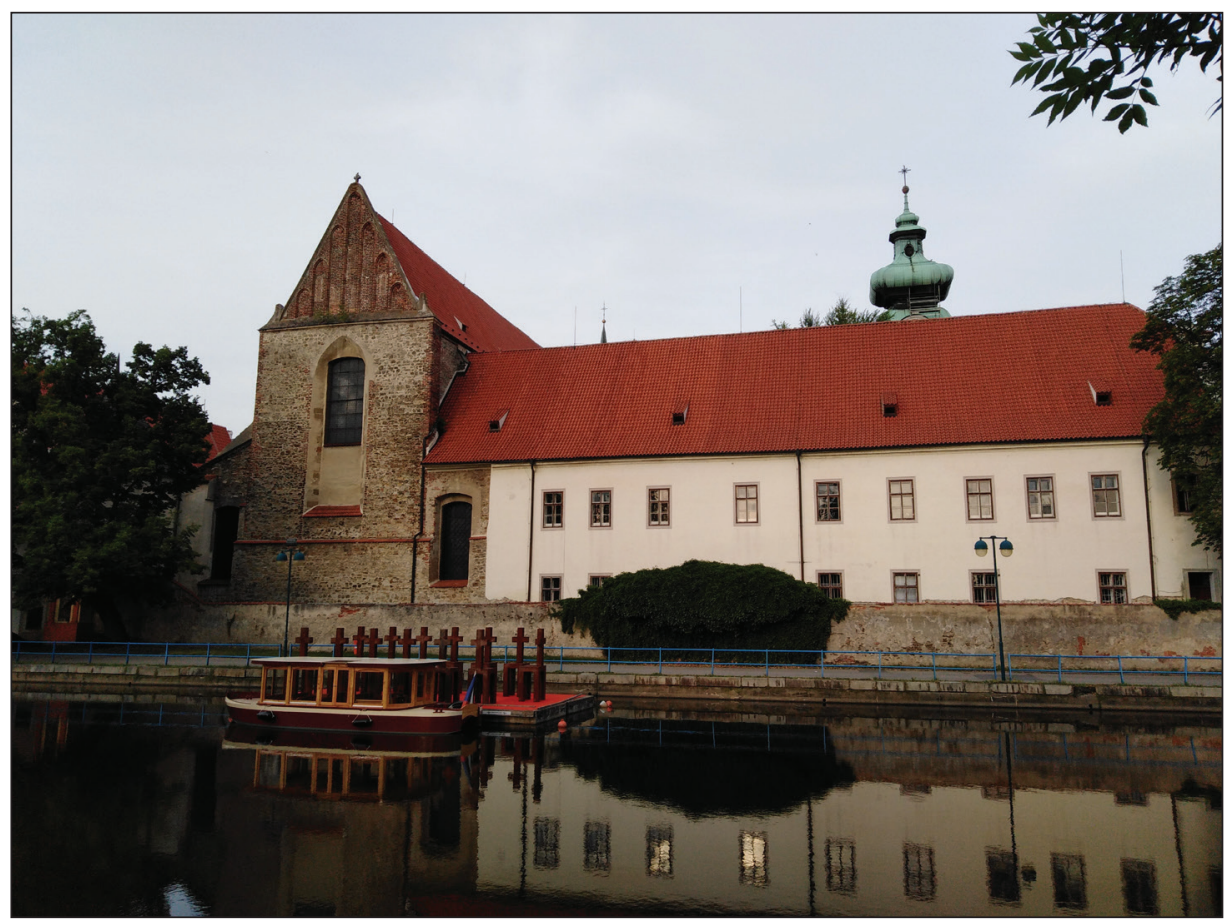

Figure 4: The Dominican monastery in České Budějovice, where Zdeněk of Šternberk, the main Czech follower of King Corvinus, was buried.

112 SOkA České Budějovice, AM České Budějovice, Cech soukeníků České Budějovice, listina I/6.

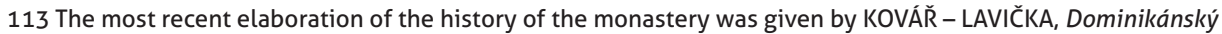
klášter v Českých Budějovicích, 103-107. Thanks to the foundation of the cloth makers, we know for 1472 the composition of the convent there - the prior was Johannes Fullonis, superior Georg Hilczenspoper and among the other 9 brethren a "boemus prepositus" Kašpar is also listed.

114 On the death of Zdeněk of Šternberk and the deposition of his body in the Dominican monastery, see: SOkA České Budějovice, AM České Budějovive, kniha Nr. 1996. 
In the legacies of the townspeople, the hospital of St Wenceslas was often remembered, temporarily administered by the knights of the cross with the red star and having its own chaplain. It had enjoyed increased attention since several deceased burghers were buried here at the time of the interdict over the city. ${ }^{115}$

The town also served as the venue for the congresses of Corvinus's side in Bohemia, and in January 1477 the king himself convoked the diet of his party in Bohemia, to which he sent as his plenipotentiary the Bishop of Oradea, Jan Filipec, and the Moravian lord Václav of Boskovice. It was directly symbolic that at the time of the body of the late Zdeněk of Šternberk being deposited at the Dominican cloister there, at the Budejovice diet his successor at the head of the Zelená Hora League and also in the post of Matthias's supreme captain (hejtman) in Bohemia was elected, namely Lord Bohuslav of Švamberk. Only a year had passed when, in the town where Bohuslav's career started, it also ended very dramatically. Bohuslav acted in his office all too independently: I previously recalled the position of Pilsen, which, referring to his lack of consent, refused to allow into the town the army led by Jan Planknar. Corvinus therefore used České Budějovice as a place where his arrest would not provoke the resistance of the populace. Bohuslav of Švamberk was lured by Václav of Boskovice from the safety of Castle Zvíkov under the pretext that he was waiting in Budějovice with an urgent message from the king. The actual arrest was not guided by the lord of Boskovice; this was executed by Jan Planknar of Kynšperk. The denizens of České Budějovice had no part in this act, but they were accused by Bohuslav's relatives of cooperation in his capture. ${ }^{116}$ Although the city was only a passive spectator and bore virtually no guilt for Bohuslav's captivity, it would be in considerable danger if the Švamberk family decided to take revenge on its populations and property; it is enough to remember what problems Brno had after 1444, when Heralt of Kunštát was executed there. ${ }^{117}$

The last direct order of King Matthias to the town of České Budějovice was a letter of 26 November 1478, where he demanded that the burgomaster and councillors subject themselves to the peace treaty that he had concluded with Vladislav Jagiellon. ${ }^{118}$ On 15 July 1479 the legal final end came for Corvinus's episode in the history of the town, and King Vladislav forgave the town of České Budějovice for the wrongdoings it had committed during the reign of King George and especially for the reign of, and

115 On the burials of burghers during the time of the interdict, see: PLETZER, České Budějovice za Matyáše Korvina, 22.

116 On the person of Bohuslav of Švamberk and his public life, see: JÁNSKÝ, Páni ze Švamberka, 150-157. On his captivity in České Budějovice PALACKÝ, Archív český VI, 60, Nr. 22; "And as you write to us of Lord Švamberk, know that we did not capture him without good causes, as then today we have him accused before the court and judge him."

117 NEUMANN, Nové prameny k dějinám husitství na Moravě, 121, Nr. 76. Brno then even wrote to Emperor Friedrich III that Jiří and Proček of Kunštát sent out letters in which they questioned the honour and good behaviour of the people of Brno. Heralt of Kunštát was justly punished by the land captain (hejtman - Jan of Cimburk at Tovačov), the bishop of Olomouc (Pavel of Miličín) and the other land lords of Moravia for his clear violence and the acts he had committed. It was thus state and not municipal power that bore responsibility for the execution. URBÁNEK, Věk poděbradský l; and ŽILA, Společenské změny na Moravě, 76-78. Brno at that sent Heralt and his retinue a safe passage for the journey to the city - in the case of České Budějovice and Švamberk's captivity, the city did not issue any similar document and therefore could not be blamed for breaking the promise. On the situation in the Kunštát family after the death of Heralt, see: PLAČEK - FUTÁK, Páni z Kunštátu, 448-450.

118 PALACKÝ, Archív český VI, 60-61, Nr. 23. 
particularly for the keeping of King Matthias. ${ }^{119}$ At the same time he confirmed all privileges granted by the previous rulers.

\section{How did Cheb do under the sovereignty of Matthias Corvinus?}

Cheb, after three difficult years, when it was heavily affected by the interdict, although twice briefly interrupted (its observance was to be cared for under the commission of the legates by the commander of the commandery of the Order of the Teutonic Knights, Johan Stier), could finally breathe out. ${ }^{120}$ Nevertheless, Cheb remained the town where King Matthias had the least real power and influence despite his success in 1472. In June 1472, representatives the town attended discussions in Německý Brod and with great satisfaction joined the ceasefire in Bohemia. ${ }^{121}$

The dextrous municipal policy continued; the representatives from the 1460 s, who had so long worked well with King George of Poděbrady, still held power. The composition of the town council had not changed much and these names regularly defended their places in the documents from the 1470s - Caspar Juncker, Jorg Schmidel, Clemens Püchelberger, Sigmund Pachmann, Franz Juncker, Wentzel Meinl and Thomas Wernher, and in 1476 also Niklas Bayer and Niklas Kessler, Prokop Woderssrewter, Erhardt Wendel and Franz Scheller. The town magistrate was Jorg Schmiedel. The decisive influence then was in the hands of the wealthy merchants. ${ }^{122}$

While Cheb paid the required tribute and began to communicate with Matthias's Bohemian officials, it did not allow the king to use Cheb soldiers in his actions, much less accept Corvinus's garrison inside their walls, although the castle there - the famous Pfalz - directly offered itself for this purpose. They could argue that it had a sufficiently strong urban Landeswehr and if necessary was capable in its "state" to raise as many as 3,000 soldiers. The town was willing to obey his orders, if of course they matched its own interests.

At the same time, Cheb practically throughout Matthias's formal rule was at war with its neighbours from the camp of Vladislav Jagiellon and even some of the Matthias's party, even founding members of the Zelená Hora League. ${ }^{123}$

The fonds of SOkA Cheb shows how carefully the town council documented the course of the disputes, amassing evidence and arguments as to why the opponent was guilty and everything that could support and justify its approach. It also understandably registered carefully all the damage incurred from the opponent and the costs connected with the conflict. It is noteworthy that unlike with Pilsen and České Budějovice, King

119 On 25 July 1479, King Matthias formally handed over to King Vladislaus II all of the population of the Czech lands, who were bound to him "by offices, subjection or any other obligations and duties" - Národní archív [National Archives Czech republic] (hereinafter NA Praha), Archív České koruny (hereinafter AČK), sign. 1764. Charter of King Vladislav SOkA České Budějovice, AM České Budějovice, Listiny 1296-1882, inv. no. 29, sign. I/29, Edition CIM III, p. 679, Nr. 404. The previous privileges of the town were confirmed also by Vladislav Jagiellon in 1479 (CIM III, 687-688 Nr. 406).

120 The interdict was taken from Rudolph of Rüdeshiem by the city, who told the people of Cheb of the withdrawal of the Bull of Sixtus IV, SOkA Cheb, Arciděkanský úřad Cheb (1388-2008), sign. 737.

121 On his participation at the meeting in Cheb PALACKÝ, Archív český XXXIV, 116.

122 SOkA Cheb, Akten aus den Jahren 1061-1800, fasc. 287, A-810, Wahlbüchlein 1384-1550 (Rathswahlen). SIEGL, Aus den Ratsakten der Egerer Stadtarchivs, 32.

123 In March, Jan of Kolovraty and at Maštov, a party member on the side of King Vladislav, complained about Kašpar Juncker and the damage he had suffered during the ceasefire. Letter of complaint to Cheb - PALACKÝ, Archív český V, 246, Nr. 55. Kolovrat complained about the people of Cheb directly to Vladislav - PALACKÝ, Archív český V, 354-355, Nr. 68. 
Matthias did not intervene personally as the judge or mediator, and evidence is also lacking for Cheb, unlike for České Budějovice, having turned to him personally. In the period 1468-1478, only three of his letters (written in Czech) to Cheb have been preserved, but that does not mean that Cheb did not attempt to take advantage of the appurtenances of Matthias's party and in October 1473 the town council did not hesitate to turn to Matthias's Bohemian supreme chancellor Jan Zajíc of Házmburk with a complaint regarding damage caused to it by the lords of Plavno. ${ }^{124}$ Jan advised to make Zdeněk of Sternberk aware of it too and promised to raise their issue himself at the closest diet, although they should themselves send envoys to it. On 8 November, Zdeněk of Šternberk and Zajíc wrote to Cheb. ${ }^{125}$

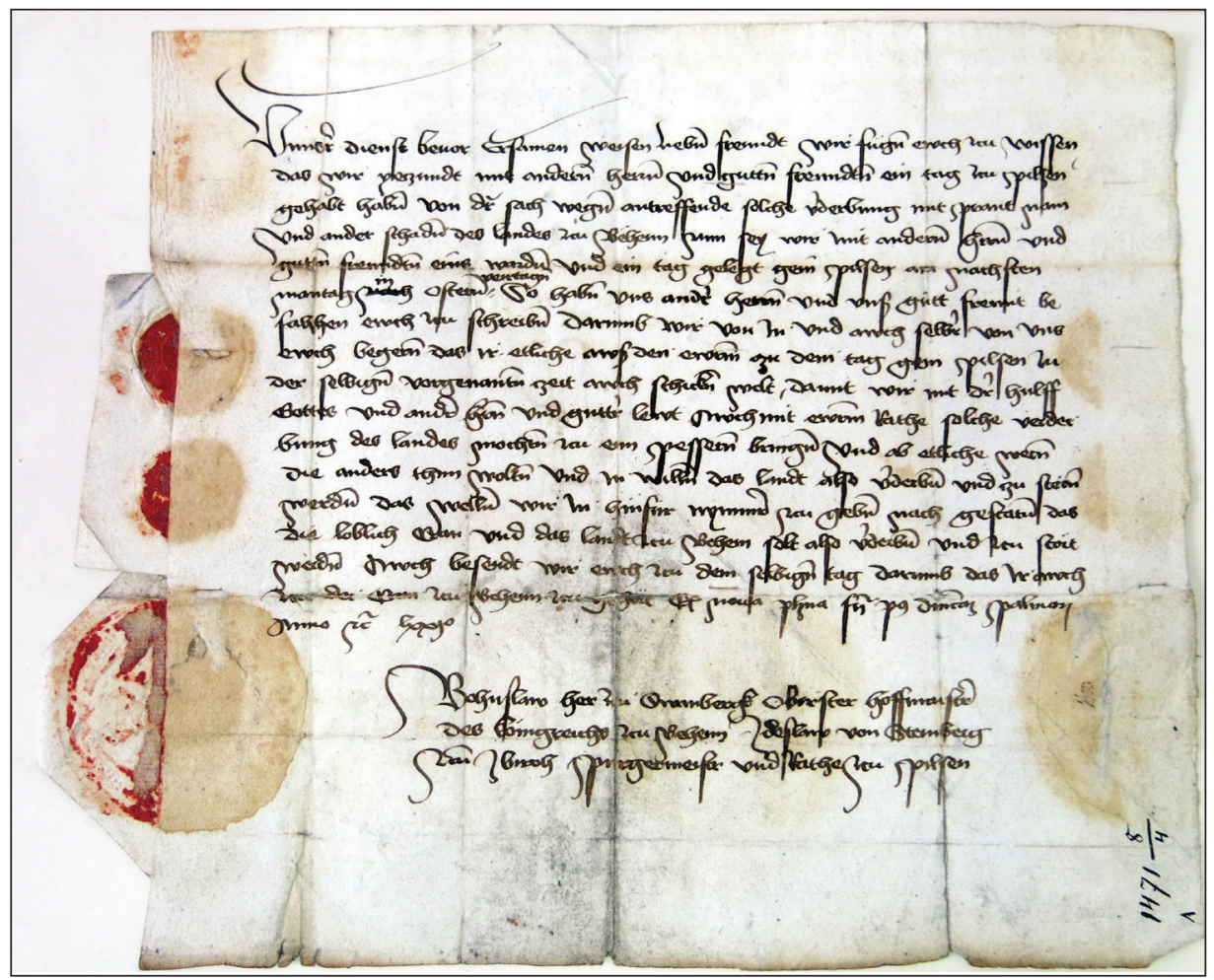

Figure 5: The Letter by Bohuslav of Švamberk to Cheb requesting that the town recognize Matthias Corvinus as its lord; 8 april 1471. SOkA Cheb, Fund 1, A70/42.

Cheb did not have damaged relations only with some aristocrats of Matthias's party but there were disputes with Pilsen as well. I have already mentioned the situation

124 Answer of Jan Zajíc to the people of Cheb in PALACKÝ, Archív český V, 349, Nr. 61.

125 SOkA Cheb, Akten aus den Jahren 1061-1800, fasc. 4, B70/23 (2). 
in 1471 when Wilhlem of Wolfštejn captured a group of merchants in Pilsen. ${ }^{126}$ In Cheb, Pilsen burgher Jan Kulper was captured and imprisoned. On 20 March 1474, King Vladislav called on the people of Cheb to release Kulper and presented his case to the chamber court, because the people of Pilsen had undertaken to take him to the court. ${ }^{127}$ However, the registry of the Chamber Court from this and the following year did not detect any case of "Kulper", so Cheb most likely disobeyed Vladislav's call. ${ }^{128}$

Cheb did not rush into the war of the three kings in the autumn of the same year, and therefore obeyed with unhidden pleasure Matthias's letter written in Czech on 4 December 1474 for the burgomaster and town council to join the ceasefire, which he had concluded with Vladislav Jagiellon in Wroclaw. In the letter of admission, they explicitly referred to Corvinus as the Bohemian king, Vladislav only with the title as the firstborn son of the Polish king. ${ }^{129}$

The ceasefire with the party of King Vladislav allowed Cheb to put all its strength into the private war with Jindrich III of Plavno, Jan of Janovice ${ }^{130}$ and Hyncík Pflug of Rabenstein. ${ }^{131}$ Jindřich was a strong competitor and the balance of forces was relatively equal, but Pflug felt the military superiority of Cheb much more painfully, and in 1477 they even conquered his subject town Neustadt an der Waldnaab. ${ }^{132}$

The ambivalent position of Cheb did not escape the Prague court; the leading advisor of the king, Prince Jindřich Minsterberský, the third son of the late King George, received precise reports from his father-in-law Albrecht Achilles, lord of not only Brandenburg, but also the Franconian areas of the Empire near Cheb. Paradoxically, more of Vladislav's letters have been preserved from 1472-1477, whereas only three of Matthias's are available $(1468,1474,1478)$. Vladislav thus contacted the town more often than Corvinus, to whom Cheb had promised obedience. ${ }^{133}$ In 1476, Vladislav's bride, the daughter of the Elector of Brandenburg Albrecht Achilles, Barbara of Brandenburg was even to enter the territory of the Bohemian kings through Cheb. In Cheb, the king's leading advisor, Prince Jindrich Minsteberský, was to welcome the bride (having in February 1467 married her old sister Ursula there) and accompany her in a ceremonial entourage to Prague. How would Corvinus react if a genuine welcome of the bride and a clear demonstration of the Jagiellonian-Hohenzollern alliance took place in a city that had promised him obedience, irrespective of the fact that there was a three-year truce with Vladislav? After Corvinus's ally John II of Zágán deprived Barbara of the Duchy of Głogów, Vladislav Jagiellon began to procrastinate over the wedding, the marriage

126 SOkA Cheb, Akten aus den Jahren 1061-1800, fasc. 6, A-76, Fehde mit Wilhelm v. Wolftein und Benesch von Kolowrat 1469-1477.

127 STRNAD, Listár̆ a listinář II, 179, Nr. 213.

128 ČELAKOVSKÝ, Registra soudu komorního 1472-1482; PALACKÝ, Archív český VII, 446-568.

129 PALACKÝ, Archív český VI, 53, Nr. 13.

130 SOkA Cheb, fund no.1, fasc. 5, 17/74, Fehde Egers mit dem Jan v. Janovitz.

131 SOkA Cheb, Akten aus den Jahren 1061-1800, fasc. 5, 17/72, Fehde Eregers gegen Heinrich III von Plauen und Planknar and 17/74, fasc. 5, and 17/76.

132 Akten aus den Jahren 1061-1800, Fehde Egers mit Hinzik von Rabenstein 1470-1480. fasc. 6, A-76. GRADL, Die Chroniken der Stadt Eger, 35-36.

133 SOkA Cheb, Akten aus den Jahren 1061-1800, Gegenkönige Wladislaus u. Mathias, fasc. 6, Nr. 72. 
never took place, and Barbara of Brandenburg never had her spectacular procession through the gates of Cheb. ${ }^{134}$

\section{Spiritual life}

Cheb was not subject to Pilsen administrators and tried to benefit from its membership of the Regensburg diocese. At the time of Matthias, it was a town of four cloisters. Thanks to the patronage right to the parish church of St Nicholas, the commandery of the Order of the Teutonic Knights held a strong position, with its headquarters in the places of today's Kasární náměstí (Barracks Square). Not even it was subject to "Bohemian superiors" and claimed the Teutonic Order's Bailiwick of Thuringia. It was guaranteed popularity with the burghers by its spittal fields of the Blessed Virgin, which was remembered by a number of Cheb denizens in their legacies from the 1470s. The actual spittal fields in Cheb were run by the knights of the cross with the red star. The importance of the local Knights of the Cross Commandery was also underlined by a large group of villages and other estates it owned in the Cheb region. In the Hussite Revolution, the Grand Master of the Order took refuge here, who resided here until the 1450 s. ${ }^{135}$

The largest cloister complex in Cheb was held at that time by the reformed branch of the Franciscans-Observants, which in the course of the 1470 s returned the good reputation of the cloister, damaged by the previous immoral behaviour of the Minorites here. There was also a women's monastery of the Poor Clares in Cheb, whose abbess in Corvinus's times was Uršula Pirk, who came from the local patrician family. The times of the interdict were soon forgotten, and on 21 March 1475 Cardinal Filip, the bishop of Oporto, even granted indulgences to the castle chapel of St Eberhardt. ${ }^{136}$

In comparison with České Budèjovice and Pilsen, Cheb could boast of a much better state of the municipal coffers and a more expensive lifestyle of its populace. In 1476 , the town council did not regret expending money on wandering actors who enriched the Easter festivities in the city. Influences from Germany manifested more strongly than in any of the West Bohemian cities, and a town dancehall was opened, albeit temporarily; burghers indulged in hunting with greyhounds and birds of prey, indeed pastimes which were not even thought of in Pilsen or Budejovice. ${ }^{137}$ There was also a rise in gambling to such an extent that the councillors felt the need to intervene, banning gambling in pubs..$^{138}$

The relative calm despite the many minor resentments in the region was disrupted in 1477. Cheb then obeyed the call of Emperor Frederick III (it after all being an imperial

134 PRIEBATSCH, Politische Korespondez, 144. RIEDEL, Codex diplom. Brandenburgensis Hauptth. III Bd II, p. 190. For the greatest detail on this issue, see: MACEK, Tři ženy krále Vladislava, 22-31 and in MACEK, Jagellonský věk I, 206-211. After him with a similar evaluation FELCMAN - FUKALA, Poděbradové, 119. Albrecht's letter on the postponement of the wedding: BACHMANN, Urkundliche Nachträge, 405, Nr. 405. On the role of Henry of Münsterberg and the prepared "taking delivery of the Brandenburg bride" in Cheb, see: ŠANDERA, Syn husitského krále, 104-105.

135 JANDEROVÁ, Působení řádu křižovníků, 24-30. RADEC (BĚLOHLÁVEK - HRADEC), Dějiny českých křižovníků, 45-46.

136 ERGBET (ERGERT), Eger, seine Vergangeheit und Gegenwart, 396-400; HALLA, Umění gotiky na Chebsku, 156159. Cardinal's indulgence charter - SOkA Cheb, Arciděkanství Cheb, Nr. 775.

137 SOkA Cheb, Archiv města Cheb (hereinafter AM Cheb), Ausgsbsbücher 1475, f. 35.

138 SIEGL, Alt-Eger in seinen Gesetzen und Verordnungen, 86-96. 
pledge!), ended its manoeuvring and delaying tactics and recognized Vladislav Jagiellon as the Bohemian king and its lord. ${ }^{139}$

Corvinus was very indignant. He was considering military retaliation, and precisely České Budějovice and, especially, Pilsen should have played a significant role in punishing the city, which had dared to fall away from him, but that turned out to be an illusory idea. Combined Hussite armies had once besieged Pilsen for 9 months and Cheb was stronger, more powerful, more populous and better fortified (towards the River Ohře even by a triple belt of walls) and was not scared by Corvinus's threats. Matthias was thus to be helped again by pressure on the part of the church; Wroclaw's Bishop Rudolf wrote to Cheb and tried to change the position of the town council, but the Silesian Estates themselves at the diet in Broumov to Matthias's disillusionment rejected the invitation of the Prague court to obey the will of Emperor Frederick and acknowledged Vladislav as their master, but refused to continue the war and concluded a new truce with King Vladislav. ${ }^{140}$

Corvinus might not have had sufficiently precise information; in any case his adherents did not stop the Cheb emissaries reaching Prague, and on 25 November 1477 Cheb representatives (three members of the town council, three knights of Cheb and three representatives of the larger municipality) swore an oath of loyalty to King Vladislav and two days later King Vladislav confirmed all of its existing privileges to the town of Cheb. ${ }^{141}$

The situation in West Bohemia already differed significantly; after the imprisonment of Bohuslav of Švamberk, King Matthias could no longer rely on the aid of the representatives of the Zelená Hora League, who could otherwise endanger connections and the Cheb merchants. A year later, however, the Cheb residents were worried that the military response to their previous year's apostasy would not come from the king after the victory of Corvinus's army at Chotěšov. Matěj Šlik warned the city council in writing that, according to a report by Burian of Gutštejn, Corvinus's army from Pilsen intended to strike at him or Cheb. ${ }^{142}$ Although Jan Planknar of Kynšperk was too experienced a warrior to try and create the illusion that he could successfully besiege such a strong city, Cheb borough villages and courtyards could have been a tempting and much easier target. Concerns in Cheb could be supported by the knowledge that Planknar also had a personal motive for such an intervention, repeatedly drawing the attention of the city council to the debt that the Cheb burghers had towards his father. And now there was real military power behind him. On 16 May 1478, Planknar wrote to the Cheb town council and declared defiance under hostilities to Cheb and its servants. ${ }^{143}$

The victory near Pilsen did not have such an effect as Corvinus had expected and the campaign for the Cheb region did not take place. Despite that, in October 1478 ,

139 On Corvinus's reaction to the emperor's recognition of King Vladislav Jagiellon, see: NAGY - NYÁRY, Magyar diplomácziai emlékek, 357, Nr. 245. NEHRING, Matthias Corvinus, 84-86. OPLL, Nachrichten aus dem mittelalterlichen Wien, $206 \mathrm{f}$.

140 Rudolf's letter SOkA Cheb, fund I, fasc. 5, A72/74, about the congress and concluded truce in Broumov, where Prince Henry presented the Silesian and Lusatian estates with the charter in which Emperor Frederick III urged the Silesians and the Lusatians to take the oath of obedience to King Vladislav, Listina $z$ Broumova z 12.8.1477-Archív České koruny VI, 115, Nr. 221, on the overall course and results, see: WINTERA, Der Beifriede von Brannau (Braunau) im Jahre 1477.

141 SOkA Cheb, Akten aus den Jahren 1061-1800, fasc. 7, A86.

142 Letter from 26 May 1478, STRNAD, Listár̆ a listinár II, 203, Nr. 244.

143 Planknar announced hostility to Cheb - original of the letter in SOkA Cheb, sign. B70/45. 
King Vladislav asked the people of Louny to provide the Cheb emissaries whom he had called to himself with an escort to the town of Most, so they would not suffer damages from enemies. ${ }^{144}$ In the conclusion of the Olomouc Peace, Cheb was already understood even by Matthias himself to be Vladislav's town.

\section{Conclusion}

The ten-year reign of Matthias Corvinus in Pilsen and České Budějovice (in the case of Cheb only five years in the end) meant economic losses for them (from the expected efforts to pass on war costs to the towns) and limitations of rights, but Corvinus's reign did not bring a merciless financial vacuuming of these municipalities and did not leave behind a beggared population. Corvinus and his officials were less hard on the representatives of the municipal administration even in comparison with Wroclaw in Silesia. ${ }^{145}$

Pilsen, Budějovice and Cheb had a significant influence on Corvinus's Bohemian policy, but they did not more significantly influence his overall behaviour towards royal cities, although the approaches to each of them showed partial differences. Situations where obedience to the sovereign's order bound the city to the consent of his subordinate official, or when the city council contacted a foreign monarch, were unusual within the overall view of royal cities in the Bohemian Crown and the Kingdom of Hungary, but there were rare episodes in Bohemian Catholic cities which passed without greater consequences. ${ }^{146}$

The stay of Matthias's garrisons was generally unpopular everywhere, but none of the towns experienced the institution of a dictatorship, imprisonment or the execution of opponents. The city councils (Corvinus never addressed the broader municipal community in his correspondence in any of the proven letters) even turned not only to Matthias's Bohemian officials, but directly to his person as Bohemian king with a request for assessment or even a direct intervention in their disputes with the nobles of his party. However, Matthias's garrisons did not help these towns much in defending the rural property that suffered invasions by Poděbrady's and later Vladislav's supporters as a consequence of leaning towards Corvinus. The towns felt their presence especially unpleasantly in 1477-1478, whereas, with most of King Vladislav's followers, they had found an acceptable modus videndi in previous years. The burghers, who were brought to power by the fall of Poděbrady's supporters and who remained there through

144 PALACKÝ, Archív český VI, 92, Nr. 24.

145 On Wroclaw and its position during the reign of Corvinus, see: GOLIŃSKI, Wroctaw od potovy XIII do poczatków XVI wieku, 96-222. Slezsko v dějinách českého státu I, 392-396. WOJTUCKA, Český král ve Vratislavi, 145-158. CZECHOWICZ, Miedzy katedra I ratuszem; CZECHOWICZ, Wratislavia-caput Coronae Regni Bohemiae?, 151-161. ČAPSKÝ, K postavení Vratislavi, 346-383.

146 An idealized view of Matthias's approach to royal cities - the king himself gives a list of freedoms of Hungarian cities that go beyond the Italian cities A. KALOUS, Královstvi a republika, 227. An overall comparison of royal cities under Matthias's rule within the Bohemian Crown lands has not yet been processed, syntheses and partial studies of Silesian history have focused their views on Wroclaw (and to a much lesser extent on Swidnica), see: DRABINA, Historia miast ślaskich w sredniowiczu; or Slezsko v dějinách českého státu l; or CZECHOWICZ, Idea i państwo. Although Mathias did not spare privileges for Lusatian cities in the beginning - see: NA Praha, AČK, sign. 1736, 1746, 1746 and 1748, the attention of Czech and German historians has focused mainly on their fates in the years of the Hussite Revolution. The situation in Moravia was substantially more favourable, were Corvinus's policy is generally reviewed, see: VÁLKA, Matyáš Korvín a Česká koruna, 313-323 and especially the mentioned KALOUS, Matyáš Korvín a moravská královská města, 97-127, which in his monograph Matthias Corvinus: Hungarian and Bohemian King, 88-90 he set out also briefly, but balanced assessment of Mathias's approach to the Hungarian royal towns. 
membership in the party of King Matthias, did not await a cruel fate and retaliation even after the Olomouc Peace.

King Vladislav did not persecute his former opponents and they did not even face an internal retaliation on the part of the urban population, whom they could legitimately blame for the enforcement of Corvinus' demands. A demonstrative bloody settlement with the past, as represented in Wroclaw in Silesia by the aforementioned execution of the leading pretender of Matthias's policies Heinz Dompnig, did not take place in Pilsen or even in České Budějovice. There was, rather, only a gradual retreat from fame and a decision to prefer to purchase in the countryside. The representatives of the former clique of Poděbrady did not return to power and only achieved partial compensation; neither Oremus nor the sons of the murdered Ondřej Puklice regained their property.

\section{BIBLIOGRAPHY}

Archiv města Plzně [Archive of the City of Pilsen], Archiv města Plzeň, Listiny

Archiv města Plzně [Archive of the City of Pilsen], Františkáni Plzeň

Archiv města Plzně [Archive of the City of Pilsen], Sbírka opisů

Archiv města Plzně [Archive of the City of Pilsen], Kniha testamentů

Národní archív [National Archives Czech republic], Archív České koruny

Státní oblastní archiv Třeboň [State Regional Archives in Třeboň], Historica Třeboň

Státní okresní archív České Budějovice [State District Archives České Budějovice], Archiv města České Budějovice, Listiny 1276-1882

Státní okresní archív České Budějovice [State District Archives České Budějovice], Archiv města České Budějovice, Liber losungarum 1482-1514

Státní okresní archív České Budějovice [State District Archives České Budějovice], Archiv města České Budějovice, Kniha nesporého a sporného soudnictví 1396-1525

Státní okresní archív České Budějovice [State District Archives České Budějovice], Liber memorabilium decanatus Budvicensus

Státní okresní archív České Budějovice [State District Archives České Budějovice], Cech soukeníků

Státní okresní archiv Cheb, [State District Archives Cheb], Akten aus den Jahren 1061-1800

Státní okresní archiv Cheb, [State District Archives Cheb], Archiv města Cheb

Státní okresní archiv Cheb, [State District Archives Cheb], Arciděkanský úřad Cheb (13882008)

BACHMANN, Adolf (ed.). Urkundliche Nachträge zur österreichisch-deutschen Geschichte im Zeitalter Kaiser Friedrich III. Fontes rerum Austriacarum XX. Wien: F. Tempsky, 1892.

ČELAKOVSKÝ, Jaromír - FRIDRICH, Gustav (eds.). Codex juris municipalis regni Bohemiae III. Privilegia regalium civitatum provincialium regni Bohemiae (1420-1526). Praha: Tiskem Národní správy FY Dr. Eduard Grégor a syn, 1948.

ČELAKOVSKÝ, Jaromír (ed.). Codex Iuris Municipalis III. Praha: Grégr a syn, 1948.

C̆ORNEJ, Petr (ed.). Království dvojího lidu. České dějiny let 1436-1526 v soudobé korespondenci. Praha: Odeon, 1989.

HOLTZ, Eberhardt (ed.). Regesten Kaiser Friedrichs III. (1440-1493) nach Archiven und Bibliotheken geordnet 26: Die Urkunden und Briefe aus den Archiven und Bibliotheken der Tschechischen Republik. Wien; Köln; Weimar: Böhlau Verlag, 2012.

CHMEL, Joseph (ed.). Monumenta Habsburgica. Sammlung Von Actenstucken Und Briefen Zur Geschichte Des Hauses Habsburg in Dem Zeitraume von 1473 bis 1576. Nr. 12-16, Wien: Aus der kaiserlich-königlichen Hof- und Staatsdruckerei, 1858.

CHMEL, Joseph (ed.). Regesta Chronologica-Diplomatica Friderici IV. Romanorum Regis (Imperatoris III.). Auszug aus den im k.k. geheimen Haus-, Hof-und Staats-Archive zu Wien sich befindenden Reischsregistratur büchern vom Jahre 1440-1493. Nebst Urkunden als Originalurkunden, Wien: Manuskripten und Büchern, 1838. 
GRADL, Heinrich (ed.). Die Chroniken der Stadt Eger. Praga: Verlag des Vereines : In Commission bei H. Dominicus, 1884.

HALLA, Karel. Umění gotiky na Chebsku. Cheb: Galerie výtvarného umění v Chebu, 2009.

KALOUSEK, Josef. Archiv český čili staré písemné památky české $i$ moravské $z$ archívi̊ domácích i cizích sebrané. Díl IX. Praha: Domestikální fond království Českého, 1889.

KALOUSEK, Josef. Archiv český čili staré písemné památky české $i$ moravské $z$ archívů domácích i cizích sebrané. Díl X. Praha: Domestikální fond království Českého, 1890.

KALOUSEK, Josef. Archiv český čili staré písemné památky české $i$ moravské $z$ archívů domácích i cizích sebrané. Díl XIV. Praha: Domestikální fond království Českého, 1895.

KALOUSEK, Josef. Archiv český čili staré písemné památky české $i$ moravské $z$ archívi̊ domácích i cizích sebrané. Díl XV. Praha: Domestikální fond království Českého, 1896.

KALOUSEK, Josef. Archiv český čili staré písemné památky české $i$ moravské $z$ archivư domácích i cizích sebrané. Díl XXI. Praha: Domestikální fond království Českého, 1903.

KRONTHAL, Bertold - WENDT, Heinrich (eds.). Sriptores rerum silesiacarum oder Sammlungder schlesischer Geschichtschreiber XIV. Politische Correspondenz Breslaus im Zeilalter des Königs Matthias Corvinus. Breslau, 1893-1894.

MARKGRAF, Hermann (ed.). Sriptores rereum Silesiacarum VIII. Politische Correspondenz Breslaus im Zeitalter Georgs von Podiebrad (1463-1469). Breslau 1874.

NAGY, Ivan - NYÁRY, Albert B. Magyar diplomácziai emlékek Mátyas király korából 14581490. Budapest: M.T. Akademia Könyvnyomdája, 1877.

PALACKÝ, František (ed.). Archív český čili staré písemné památky české $i$ moravské $z$ archívio domácích i cizích sebrané I, II, III, V, VI. Praha 1840,1842, 1844, 1846, 1872.

PALACKÝ, František (ed.). Urkundliche Beitrage zur Geschichte Böhmens und seiner Nachbärlander zur Zeitalter Georgs von Podiebrad (1450-1471). Wien: Kaiserlich-Königliche Hof- und Staatsdr., 1860.

PRIEBATSCH, Felix (ed.). Politische Correspondenz des Kurfürsten Albrecht Achilles II. 14751480. Leipzig, 1897.

RIEDEL, Adolph Friedrich Johann (ed.). Codex diplomaticus Brandenburgensis: Sammlung der Urkunden, Chroniken und sonstigen Quellschriften. Hauth III Bd II. Berlin: Morin, 1860.

ROTH Gunhild (ed.). Magister Petr Eschenloer, Geschichte der Stad Breslau 1, 2. Münster; New York; München; Berlin Waxmann, 2003.

STRNAD, Josef (ed.). Listár̆ a listinář královského města Plzně a druhdy poddaných osad II (1450-1526). Plzeň: Městské historické museum, 1905.

WINTERA, Laurenz (ed.). Der Beifriede von Brannau im Jahre 147ns für die Geschichte der Deutschen in Böhmen 7 Mitteilungen des Vereins für die Geschichte der Deutschen in Böhmen 37, 1899.

ADÁMEK, Jan. Oltářnická beneficia v Českých Budějovicích v předhusitské době [Altar benefit in České Budějovice in the pre-Hussite period]. In: Jihočeský sbornik historický. 1995, Yearbook 64, pp. 34-73.

ADÁMEK, Jan - HANSOVÁ, Jarmila - KOVÁŘ, Daniel - LAVIČKA, Roman - MAREŠ, Zdeněk - THOMOVÁ, Zuzana. Katedrála sv. Mikuláše v Českých Budějovicích. České Budějovice: Národní památkový ústav, územní odborné pracoviště v Českých Budějovicích, 2014.

BĚLOHLÁVEK, Miloslav. Dějiny Plzně. Plzeň: Západočeské nakladatelství, 1965.

BĚLOHLÁVEK, Miloslav. Plzeň a Mikuláš Bakalář. In: KOHÚT, Leo - ALTMANN, Ursula - ŠPETKA, Jozef (eds.). Mikuláš Bakalár Štetina: Štúdie a materiály o životě a diele slovenského prvotlačiara v Plzni. Bratislava: Slovenská akadémia vied, 1966, pp. 74-85.

BĚLOHLÁVEK, Václav - HRADEC, Josef. Dějiny českých kř́žovníků s červenou hvězdou. Praha: Nákladem Řádu českých křižovníků, 1930.

BURKOŇOVÁ, Eva. Vztah královské politiky Jiřího z Poděbrad k Českým Budějovicím a Plzni. In: Folia Historica Bohemica 12. Praha: Ústav československých a světových dějin ČSAV, 1988, pp. 349-382. 
CZECHOWICZ, Boguslaw. Idea i państwo. Korona Królewstwa Czech w latach 1457-1547. Tom III. Mathias primus Dei gratia rex Bohemiae. Rehabilitacja nieuznawanego króla [Idea and State: The Crown of the Bohemian Kingdom in 1457 - 1547, Volume III, Mathias primus Dei gratia rex Bohemiae. Rehabilitation of an Unrecognized King]. Wrocław: Ouaestio, 2017.

CZECHOWICZ, Boguslaw. Miedzy katedra I ratuszem: Polityczne uwarunkowanie sztuki Wroctawia u schytku średinowiecza [Between the cathedral and the town hall: Political conditioning of Wrocław's art at the end of the Middle Ages]. Warszawa: DiG, 2008.

CZECHOWICZ, Bogusław. O miejsce w koronie: król Jerzy a Wrocław. In: Východočeské listy historické 25. Hradec Králové: Historický ústav Filozofické fakulty Univerzity Hradec Králové, 2008, pp. 55-66.

CZECHOWICZ, Bogusław. Wratislavia - caput Coronae Regni Bohemiae? Praga i Wrocław w artystycznym dialogi w XV wieku [Wratislavia - caput Coronae Regni Bohemiae? Prague and Wrocław in an artistic dialogue in the 15th century]. In: Ślask I Czechy, pp. 151-161.

ČAPEK, Ladislav. Město České Budějovice a jeho zázemí ve vrcholném a pozdním středověku. In: Archaeologia historica 37, 2012, pp. 143-164.

ČAPSKÝ, Martin. Hejtmanský úruad v politických ambicích pozdně středověké Vratislavi. In: BOBKOVÁ, Lenka - ČAPSKÝ, Martin - KORBELÁŘOVÁ, Irena (eds.). Hejtmanská správa ve vedlejších zemích Koruny české. Opava: Ústav českých dějin Filosofické fakulty UK, 2009, pp. 77-102.

ČAPSKÝ, Martin. K postavení Vratislavi v českých korunních zemích v pozdním středověku [On the position of Wroclaw in the Bohemian Crown lands in the late Middle Ages]. In: Český časopis historický, 2017, vol. 115, no. 2, pp. 346-383.

ČAPSKÝ, Martin. Komunikace ve středověkém městě [Communication in the medieval city]. In: ČAPSKÝ, Martin et al. Komunikace ve středověkých městech. Opava: Slezská univerzita v Opavě, 2014, pp. 9-38.

ČAPSKÝ, Martin. Město pod vládou kazatelů. Charismatičtí náboženští vưdci ve střetu s městskou radu v pozdně středověkých českých korunních zemích. Praha: Argo, 2015.

ČECHURA, Jaroslav. České Budějovice - př́klad vytváření městského velkostatku ve středověkých Čechách. In: Jihočeský sborník historický 54, 1985, pp. 161-173.

ČECHURA, Nová interpretace českobudějovické berní knihy z let 1396-1416 [A new interpretation of the Ceské Budějovice tax records from 1396-1416]. In: Jihočeský sborník historický, 1987, vol. 56, pp. 1-12.

ČERNÝ, Vojtěch. Zklamané naděje. Pobyt Matyáše Korvína ve Vratislavi roku 1469. In: DOLEŽALOVÁ, Eva - NOVOTNÝ, Robert - SOUKUP, Pavel (eds.). Evropa a Čechy na konci středověku: Sborník př́spěvků věnovaných Františku Šmahelovi. Praha: Centrum medievistických studií, 2004, pp. 187-194.

DRABINA, Jan. Historia miast ślaskich $w$ sredniowiczu [History of the Silesian cities in the Middle Ages]. Kraków: Impuls, 2000.

ERBEN, Karel Jaromír. Ondřej Puklice ze Vstuh, měštěnín Budějovický (†1467). In: Časopis Českého musea 20, 1846, pp. 163-211.

ERGERT, Rudolf. Eger, seine Vergangeheit und Gegenwart. Eger: Rudolf Ergert, 1929.

FAIT, Jiří et al. Gotika v západních Čechách (1230-1530) [The Gothic in West Bohemia (12301530)]. Praha: Národní galerie, 1995.

FELCMAN, Ondřej - FUKALA, Radek et al. Poděbradové. Rod českomoravských pánů, kladských hrabat a slezských knížat. Praha: Nakladatelství Lidové noviny, 2008.

FIALOVÁ, Anděla. Z korespondence Hilaria Litoměřického. In: Jihočeský sborník historický 36,1966 , pp. 68-89.

GILEWSKA-DUBIS, Janina. Źycie codzienne miesczan wroclawskich w dobie średniowiecza. Wrocław: Wydawnictwo Dolnoślasskie, 2000.

GOLIŃSKI, Mateusz. Wrocław od połovy XIII do poczatków XVI wieku [Wroclaw from the middle of the $8^{\text {th }}$ to the beginning of the $16^{\text {th }}$ centuries]. In: BUŚKO, Cezary et al. Historia Wrocławia. Od Pradziejów do końca czasów habsburských. Wrocław: Wydawnictwo Dolnoślaskie, 2001, pp. 96-222. 
HEJNIC, Josef. Hilaria Litoměřického Hystoria civitatis Plznensis, její prameny a literámí význam. In: Listy filologické/Folia philologica, 1984, vol. 107, no. 4, pp. 240-245.

KADLEC, Jaroslav. Hilarius Litoměřický v čele duchovenstva podjednou. In memoriam Josefa Macka (1922-1991). In: Práce Historického ústavu Akademie věd České republiky. Řada C, Miscellanea. Praha: Historický ústav, 1996, pp. 187-196.

HEJNIC, Josef - POLÍVKA, Miroslav. Plzeñ v husitské revoluci: Hilaria Litoměřického „Historie města Plzněc, její edice a historický rozbor. Praha: Ústav československých a světových dějin, 1987.

HUYER, Reinhold. Die Münzstätte in Budweis und der Rudolfstädter Bergbau. In: Numismatische Zeitschrift 19, 1926, pp. 123-126.

HUYER, Reinhold. Zur Geschichte des Stadthauses Nro. 10 (Mallner). In: Budweiser Zeitung, 1910, vol. 49, no. 33, pp. 1-2.

JANDEROVÁ, Andrea. Působení řádu křížovníků s červenou hvězdou v západních a severozápadních Čechách do roku 1526. Majetková držba, špitálnictví a farní správa. Master's thesis, Karlova univerzita v Praze, 2007.

JÁNSKÝ, Jiří. Páni ze Švamberka. Pětisetletá sága s erbem labutě. Domažlice: Nakladatelství Českého lesa, 2006.

JÁNSKÝ, Jiří. Kronika česko-bavorské hranice IV. (1458-1478). Domažlice: Nakladatelství Českého lesa, 2004.

JANOUŠEK, Bohumír. Rod Klariců a rychtářský úřad v Českých Budějovicích. In: Jihočeský sborník historický 34. České Budějovice: Jihočeské muzeum, 1965, pp. 1-13.

KALOUS, Antonín. Matyáš Korvín (1443-1490). Uherský a český král. České Budějovice: Veduta, 2009.

KALOUS, Antonín. Matyáš Korvín a moravská královská města. In: Korunní země v dějinách českého státu II. Společné a rozdílné. Česká koruna v životě a vědomí jejích obyvatel ve 14. 16. století. Praha: Albis international, 2005, pp. 97-128.

KALOUS, Antonín. Království a republika slepýma očima Aurelia Brandoliniho. In: KALOUS, Antonín - STEJSKAL, Jan - ŠRÁMEK, Josef (eds.). Jedinec a evropská společnost do 19. století. Olomouc: Filozofická fakulta Univerzity Palackého v Olomouci 2014, pp. 214-230.

KOVÁŘ, Daniel. Tragédie Ondřeje Puklice: Budějovický purkmistr a jeho zavraždění 25. května 1467. České Budějovice: Historicko-vlastivědný spolek v Českých Budějovicích, 2007.

KOVÁŘ, Daniel - LAVIČKA, Roman. Dominikánský klášter v Českých Budějovicích. České Budějovice: Národní památkový ústav, 2017.

KREUTZ, Bernhard. Städtebünde und Städtenetz am Mittelrhein im 13. und 14. Jahrhundert. Trier: Kliomedia, 2005.

KUBŮ, František. Chebský městský stát: Počátky a vrcholné období do počátku 16. století. České Budějovice: Veduta, 2006.

KUMPERA, Jan (red.). Dějiny západních Čech I. Od pravěku do 18. století. Plzeň: Nakladatelství Ševčík, 2004.

KUROWSKI, Gertrud. Heinz Dompnig. Der Landeshauptmann von Breslau; Roman. Breslau: J. Handel, 1926.

MACEK, Josef. Tři ženy krále Vladislava. Praha: Mladá fronta, 1992.

MACEK, Josef. Jagellonský věk v českých zemích (1471-1526) 1.2: Hospodářská základna a královská moc. Praha: Academia, 2001.

MACEK, Josef. Jagellonský věk v českých zemích (1471-1526) 4.4. Praha: Academia, 2001. MALIVÁNKOVÁ-WASKOVÁ, Marie - DOUŠA, Jaroslav et al. Dějiny města Plzně 1. Do roku 1788 [The History of the City of Pilsen 1: Up to 1788]. Plzeň: mesto Plzeň, 2014.

MILITKÝ, Jiří. Mincovna Matyáše Korvína v Českých Budějovicích a otázka identifikace její produkce. In: POLANSKÝ, Luboš (ed.). Pavel Radoměřský: Sborník numismatických studií k 75. výročí narození. Praha: Česká numismatická společnost, 2002, pp. 62-80.

NEHRING, Karl. Matthias Corvinus, Kaiser Friedrich III, und das Reich: Zum hunyadischhabsburgischen Gegensatz im Donauraum. München: R. Oldenbourg, 1975.

NECHANICKÝ, Zdeněk. Matyáš Korvín a jeho mincovnictví v českých zemích. Př́loha Sběratelských zpráv 78. Hradec Králové: Ceská numismatická společnost, 1992. 
NEUMANN, Augustin (ed.). Nové prameny k dějinám husitství na Moravě [New sources on the history of the Hussites in Moravia]. Olomouc: Matice Cyrilometodějská, 1930.

OPLL, Ferdinand. Nachrichten aus dem mittelalterlichen Wien: Zeitgenossen berichten. Wien: Böhlau Verlag, 1995.

PLAČEK, Miroslav - FUTÁK, Peter. Páni z Kunštátu [The Lords of Kunstat]. Praha: NLN Nakladatelství Lidové noviny, 2006.

PLETZER, Karel. České Budějovice za Matyáše Korvína. In: Minulost a současnost Českých Budějovic: studie a materiály I. České Budějovice: Městský národní výbor, 1969, pp. 17-56.

PLETZER, Karel. Dr. Václav Mondl z Budějovic. In: Jihočeský sborník historický 60-61, 19911992, pp. 85-87.

PLETZER, Karel. Ondřej Puklice ze Vztuh a národnostní poměry v Českých Budějovicích před rokem 1526. In: Výběr, 1994, vol. 31, no. 1, pp. 9-14.

RADEK, David. Vratislavský měštan Heinz Domping (+1490) a symbolická komunikace na sklonku středověku. In: ČAPSKÝ, Martin et al. Komunikace ve středověkých městech. Opava: Slezska univerzita v Opavě, 2014, pp. 123-136.

RAK, Petr. Česká venkovská královská města v politice Jiřího z Poděbrad. In: Sborník historický 32. Praha: Historický ústav ČSAV, 1985, pp. 5-51.

SIEGL, Karl. Aus den Ratsakten der Egerer Stadtarchivs. Sonderdruck aus "Unser Egerland", "Zeitschrift für Heimaterkundung und Heimatpflege". Eger: Alois John, 1922.

SIEGL, Karl. Alt-Eger in seinen Gesetzen und Verordnungen. Augsburg; Kassel: Johannes Stauda, 1927.

Slezsko v dějinách českého státu I: Od pravěku do roku 1490 [Silesia in the history of the Bohemian state I: From prehistory to 1490]. Praha: NLN - Nakladatelství Lidové noviny, 2012.

SOUKUP, Jan. Katedrála svatého Bartoloměje v Plzni. Plzeň: Agentura David a Jakub, 2012.

SULITKOVÁ, Ludmila. Město, fara a škola ve středověku (na příkladu královského města Brna). In: RÁBIK, Vladimír et al. Vývoj cirkevnej správy na Slovensku. Krakow: Bibliotheca historica Tyrnaviensia, 2010, pp. 279-296.

SULITKOVÁ, Ludmila - BOROVSKÝ, Tomáš. Moravská královská města a Jiří z Poděbrad. In: ŠANDERA, Martin - BERAN, Zdeněk et al. Poděbradská éra v zemích České koruny. Praha: Nakladatelství Lidové noviny, 2016, pp. 41-55.

ŠANDERA, Martin. Jindřich starši z Minsterberka. Syn husitského krále. Velký hráč s nízkými kartami. Praha: Vyšehrad, 2016.

ŠIMEČEK, Zdeněk. Angličtí křižáci v českých Budějovicích. In: Jihočeský sborník historický 26, 1957, pp. 17-23.

ŠIMƯNEK, Robert. Správní systém šlechtického dominia v pozdně středověkých Čechách. Rožmberská doména 1418-1472. Praha: Historický ústav, 2005.

ŠPIRKOVÁ, Věra. Židovská komunita v Plzni. Domažlice: Nakladatelství Českého lesa, 2000.

ŠVÁB, Milan. Nápisy u fresek v kapli sv. Barbory františkánského kláštera v Plzni [Inscriptions by frescoes in the chapel of St Barbara of the Franciscan Friary in Pilsen]. In: Minulostí západočeského kraje 17, 1981, 196-197.

THIEME, André - TRESP, Uwe (ed.). Eger 1459: Fürstentreffen zwischen Sachsen, Böhmen und ihren Nachbarn: dynastische Politik, fürstliche Repräsentation und kulturelle Verflechtung = Cheb 1459: setkání panovníků Saska, Čech a jejich sousedů: dynastická politika, panovnická reprezentace a kulturní vazby [Cheb 1459: Meeting of the rulers of Saxony, Bohemia and their neighbours: dynastic policy, sovereign representation and cultural ties]. Dössel: Janos Stekovics, 2011.

URBAN, Wincenty. Skiczie (Szkice) z dziejów diecezji wrocławskiej: Biskup Jan Roth [Sketches from the History of the Diocese of Wroclaw: Bishop Jan Roth]. In: Studia Theologica Varsaviensia 5, 1967, pp. 11-72.

URBÁNEK, Rudolf. Věk poděbradský I: České dějiny III / 1 [The Age of Poděbrady I: Czech History III/1]. Praha: Jan Laichter, 1915.

VÁLKA, Josef. Matyáš Korvín a Česká koruna [Matthias Corvinus and the Bohemian Crown]. In: Časopis Matice moravské, 1991, vol. 110, no. 2, pp. 313-323. 
VAŘEKA, Pavel - ROŽMBERSKÝ, Petr - HOLATA, Lukáš - SCHEJBALOVÁ, Zdeňka. Vesnické zázemí středověké Nové Plzně [Village hinterland of medieval New Pilsen]. In: Archaeologia historica. 2012, Yearbook 37, no. 1, pp. 289-318.

VOJTÍŠKOVÁ, Jana. Středověké a raně novověké městské kanceláře: široké téma pro široké využití [Medieval and early modern city offices: a wide topic for wide use]. In: Sborník archivních prací, 2018, vol. 68, no. 1, pp. 85-93.

VONDRÁČEK, Milan. Panovnická politika vưči městům ve světle písemností Ladislava Pohrobka a Jiř́ího z Poděbrad [Sovereign policy to the cities in the light of the documents of Ladislaus the Posthumous and George of Poděbrady]. In: Acta univeritatis Caroliae Philosphica et historica. Z pomocných věd historických 10, 1992, pp. 161-165.

WOJTUCKA, Jana. Český král ve Vratislavi. Proměny vzájemného vztahu panovníka a jeho města od 14. do začátku 16. století [The Bohemian king in Wroclaw: Transformations of the mutual relation of the sovereign and his city from the $14^{\text {th }}$ to the beginning of the $16^{\text {th }}$ centuries]. In: DÁŇOVÁ, Helena - KLÍPA, Jan - SZOLÁROVÁ, Helena (eds.). Slezsko, země Koruny české. Historie a kultura 1300-1740. Praha: Národní galerie, 2008, pp. 145-160.

ŽILA, Miloš. Společenské změny na Moravě v letech 1437-1453 [Social changes in Moravia in 1437-1453]. PhD diss, Masarykova univerzita v Brne, 2010. 